\title{
Phosphorus in Denmark: national and regional anthropogenic flows
}

KlingImair, Manfred; Lemming, Camilla; Jensen, Lars Stoumann; Rechberger, Helmut; Astrup, Thomas Fruergaard; Scheutz, Charlotte

\author{
Published in: \\ Resources, Conservation and Recycling
}

Link to article, DOI:

10.1016/j.resconrec.2015.09.019

Publication date:

2015

Document Version

Peer reviewed version

Link back to DTU Orbit

Citation (APA):

Klinglmair, M., Lemming, C., Jensen, L. S., Rechberger, H., Astrup, T. F., \& Scheutz, C. (2015). Phosphorus in Denmark: national and regional anthropogenic flows. Resources, Conservation and Recycling, 105(Part B), 311324. https://doi.org/10.1016/j.resconrec.2015.09.019

\section{General rights}

Copyright and moral rights for the publications made accessible in the public portal are retained by the authors and/or other copyright owners and it is a condition of accessing publications that users recognise and abide by the legal requirements associated with these rights.

- Users may download and print one copy of any publication from the public portal for the purpose of private study or research.

- You may not further distribute the material or use it for any profit-making activity or commercial gain

- You may freely distribute the URL identifying the publication in the public portal 


\section{Phosphorus in Denmark: national and regional}

\section{anthropogenic flows}

1) Technical University of Denmark, Department of Environmental Engineering 


\section{ABSTRACT}

2 Substance flow analyses (SFA) of phosphorus (P) have been examined on a national or supra-

3 national level in various recent studies. SFA studies of P on the country scale or larger can have

4 limited informative value; large differences between $\mathrm{P}$ budgets exist within countries and are

5 easily obscured by country-wide average values. To quantify and evaluate these imbalances we

6 integrated a country-scale and regional-scale model of the Danish anthropogenic P flows and

7 stocks. We examine three spatial regions with regard to agriculture, as the main driver for $\mathrm{P}$ use,

8 and waste management, the crucial sector for P recovery. The regions are characterised by their

9 differences in agricultural practice, population and industrial density. We show considerable

10 variation in $\mathrm{P}$ flows within the country. First, these are driven by agriculture, with mineral

11 fertiliser inputs varying between 3 and $5 \mathrm{~kg} \mathrm{ha}^{-1} \mathrm{yr}^{-1}$, and animal feedstuff inputs between 5 and

$1219 \mathrm{~kg} \mathrm{ha}^{-1} \mathrm{yr}^{-1}$. We identified surpluses especially in areas with a larger proportion of animal

13 husbandry, owing to additional application of manure in excess of crop P demand. However,

14 redistribution of the large amounts of $\mathrm{P}$ in manure is not feasible owing to transport limitations.

15 Second, waste management, closely linked to population and industrial density is the driver

16 behind differences in recoverable P flows. Current amounts of potentially recoverable P cannot

17 change the reliance on primary $\mathrm{P}$. The most immediate $\mathrm{P}$ re-use potential exists in the areas

18 around the eastern urban agglomerations, from more complete recovery of sewage sludge (with

19 unrecovered $\mathrm{P}$ amounts of up to 33\% of $\mathrm{P}$ in current mineral fertiliser imports) and the biowaste

20 fraction in municipal solid waste currently not collected separately (24\% of P in current mineral

21 fertiliser imports), since this region shows both the highest proportion of crop production and

22 fertiliser use and lowest soil P budget. 
1 KEYWORDS: substance flow analysis; material flow analysis; phosphorus; Denmark; waste 2 management; agriculture; resource management 


\section{1. INTRODUCTION}

Phosphorus (P), an essential plant nutrient mined from the earth’s crust as phosphate rock,

3 is a crucial resource for future food security. There is no substitute for $\mathrm{P}$ in agricultural

4 production. From a European perspective, economic P scarcity is a potential geopolitical and

5 strategic threat, as Europe has very limited rock phosphate reserves within its own territory. In

6 2012, the EU-27 imported 8230 Gg and exported 60 Gg of phosphate rock (IFA 2013). An

7 increasing worldwide phosphate demand combined with a high dependence on phosphate rock

8 imports from a limited number of suppliers outside the EU-28, with Russia and Morocco

9 providing $49 \%$ of imports, may pose geopolitical risks to a safe future supply. While no prospect

10 of global “peak phosphorus” looms in the foreseeable future, market-caused, demand-driven

11 peaks, production plateaus, and geopolitical contingencies remain a risk in the short, mid-term,

12 and particularly long-term supply of P (Scholz \& Wellmer 2013). In 2014, phosphate rock has

13 been included in the EU’s list of critical raw materials (European Commission 2014). .

14 Dissipative losses form the flip side of concerns with phosphorus supply, both with regard

15 to diminishing our ability to recover $\mathrm{P}$, and to the pollution potential of $\mathrm{P}$ lost to the natural

16 environment (e.g. Scholz et al. 2014). The global nature of modern food production has led to the

17 P cycle being “broken” on a global scale (Ashley et al. 2011), with P-containing fertiliser,

18 livestock feed and food products being shipped over global distances, adding to the P balance of

19 importing regions while necessitating the replenishment of soils with fertilisers in exporting

20 regions. This open cycle repeats itself also on a more local scale, where $\mathrm{P}$ is lost dissipatively

21 through inefficient use in agriculture or in the form of waste, animal manure applied in excess of

22 plant demand, other organic waste, and waste water, which will be lost if not recycled

23 appropriately. These waste flows are potential sources of P, and need to be identified and

24 quantified if the utilisation of $\mathrm{P}$ recovered from waste or manure streams in a particular region is 
1 to be increased, and the dependence on mineral P imports reduced (Smil 2000; Schröder et al.

2 2011; Cordell et al. 2011).

3 Agriculture and food production, and the handling of the resulting wastes, are the

4 quantitatively most important processes in the anthropogenic P cycle. In analyses of the

5 anthropogenic $\mathrm{P}$ cycle, flows to and from agriculture and food production tend to be more than an

6 order of magnitude larger than other flows (e.g. Chowdhury et al. 2014). These flows provide

7 significant potentials for recovery and reuse of $\mathrm{P}$, mainly via the solid organic waste and

8 municipal wastewater (and resulting sewage sludge) streams, as well as the large quantities of P

9 in animal manure.

10 The supply, pathways, stocks and losses of $\mathrm{P}$ in the anthroposphere have been examined

11 from a resource perspective on a national or larger level in various recent European studies, e.g.

12 by Binder et al. (2009) for Switzerland; Ott \& Rechberger (2012) for the EU-15; and Egle et al.

13 (2014) for Austria. P balances with more limited scope on individual economic sectors have been

14 put forward for Europe e.g. by Sibbesen \& Runge-Metzger (1992) on P in European agriculture;

15 Nesme et al. (2011) on agriculture in Bordeaux, France; Senthilkumar et al. (2011) on agriculture

16 in selected French regions; Cooper \& Carliell-Marquet (2013) on the food production and

17 consumption system in the UK; and Sokka et al. (2004) on P flows in the Finnish waste

18 management system. Vinther \& Olsen (2013) present a 10-year timeline of nutrient balances

19 (nitrogen, phosphorus, potassium) in Danish agriculture, calculating overall annual accumulation

20 and losses. Chowdhury et al. (2014) provide a comprehensive overview of substance flow

21 analyses conducted for P.

22 The goal of the present work was to develop a study of a detailed and complete national-

23 scale system of anthropogenic $\mathrm{P}$ flows and stocks from a resource perspective, and integrate it

24 with a more detailed and geographically differentiated analysis. Denmark is an informative 
subject for this study, since it has no noteworthy P deposits and combines a homogeneous

2 geography with clearly different anthropogenic $\mathrm{P}$ cycles within a small area, and industrialised

3 agriculture and modern waste management with good data availability. Within our national-scale

4 model, we focus on a regional evaluation of the activities critical for $\mathrm{P}$ turnover and recovery in

5 an economy, namely, agriculture and waste management. Differences in these sectors can be

6 considerable within a country, and may present a major hurdle to informing P management

$7 \quad$ policy within a country when linking recovery of $\mathrm{P}$ to its reuse in agriculture. Such differences

8 would remain more obscure in an MFA purely on the country scale. We aimed, first, to assess

9 anthropogenic P flows for Denmark, both at the scale of the entire country and its economy, and

10 on a smaller, regional level. The latter was done in order to identify flows and regions holding

11 potential for increased recycling of P. We divided the analysis into three regions with varying

12 population densities, and dominated by either pure crop production, animal husbandry, or a more

13 mixed system with animal husbandry and cropping, leading to imbalanced P management.

14 Secondly, we discuss the main barriers to more efficient recovery and reuse of $\mathrm{P}$, and quantify

15 future potentials for substituting mineral $\mathrm{P}$ fertilisers and more efficient utilization of $\mathrm{P}$ resources 16 in Denmark.

17

18 2. METHODOLOGY

\section{2.1. Material/Substance Flow Analysis}

21 We use the approach of Material, or Substance Flow Analysis (MFA/SFA) as defined by

22 Baccini and Brunner (1991), in which flows and stocks of a material or substance are quantified

23 within a spatial and temporal system boundary with all im- and exports, establishing a material

24 balance of the system. This study was conducted for a substance (P); the term "substance flow 
1 analysis” is therefore appropriate. Flows, stocks, and stock changes within the system are

2 quantified. The STAN version 2.5 software (Cencic \& Rechberger 2008) was used for

3 consideration of uncertainties, data reconciliation, and visualization.

\section{$5 \quad$ 2.2. System definition}

\subsubsection{System boundary}

We define the spatial system boundary as the land area of Denmark, excluding the Faroe

9 Islands and Greenland. The hydrosphere is outside the system boundary we consider, as it does

10 not fully form a part of the anthropogenic P cycle. We consider P flows to water bodies as losses

11 with respect to resource recovery. The study was conducted for 2011 owing to highest

12 availability and completeness of data at the time of writing; where data of adjacent years were

13 available, we used the 3-year average value to account for annual variations. The concentration

14 on 1 year means that this study is a snapshot not intended or suitable to discuss longer-term

15 trends and fluctuations; the uncertainty introduced by variations in P flows between years has to

16 be borne in mind when making statements on such trends.

\subsubsection{Processes and system layout}

19 At the outset of this study, clear differences in agricultural practice and

20 population/industrial density, especially between the east with the largest urban agglomerations

21 and the northwest, suggested a partial division of the MFA system into several regions. For a

22 meaningful assessment of P management in Denmark, a sub-national, regional perspective on

23 agriculture and waste management is useful. These processes are key to both the anthropogenic $\mathrm{P}$

24 turnover and the material flows holding potentially recoverable quantities of $\mathrm{P}$. This regional 
1 division is certainly dependent on the system (i.e. country) and substance under study. The

2 availability of regionalised data for the majority of P-containing material flows further facilitated

3 this system layout. We divided the SFA system along administrative borders, which also

4 corresponded with differences in agricultural practice (e.g. Figure 1): Sjaelland (Zealand) and

5 region Hovedstaden (the capital region, including the island of Bornholm in the Baltic Sea) in the

6 east of the country, here denoted region A; Syddanmark (South Denmark) and Midtjylland (Mid-

7 Jutland), region B; and Nordjylland (North Jutland), denoted region C. 


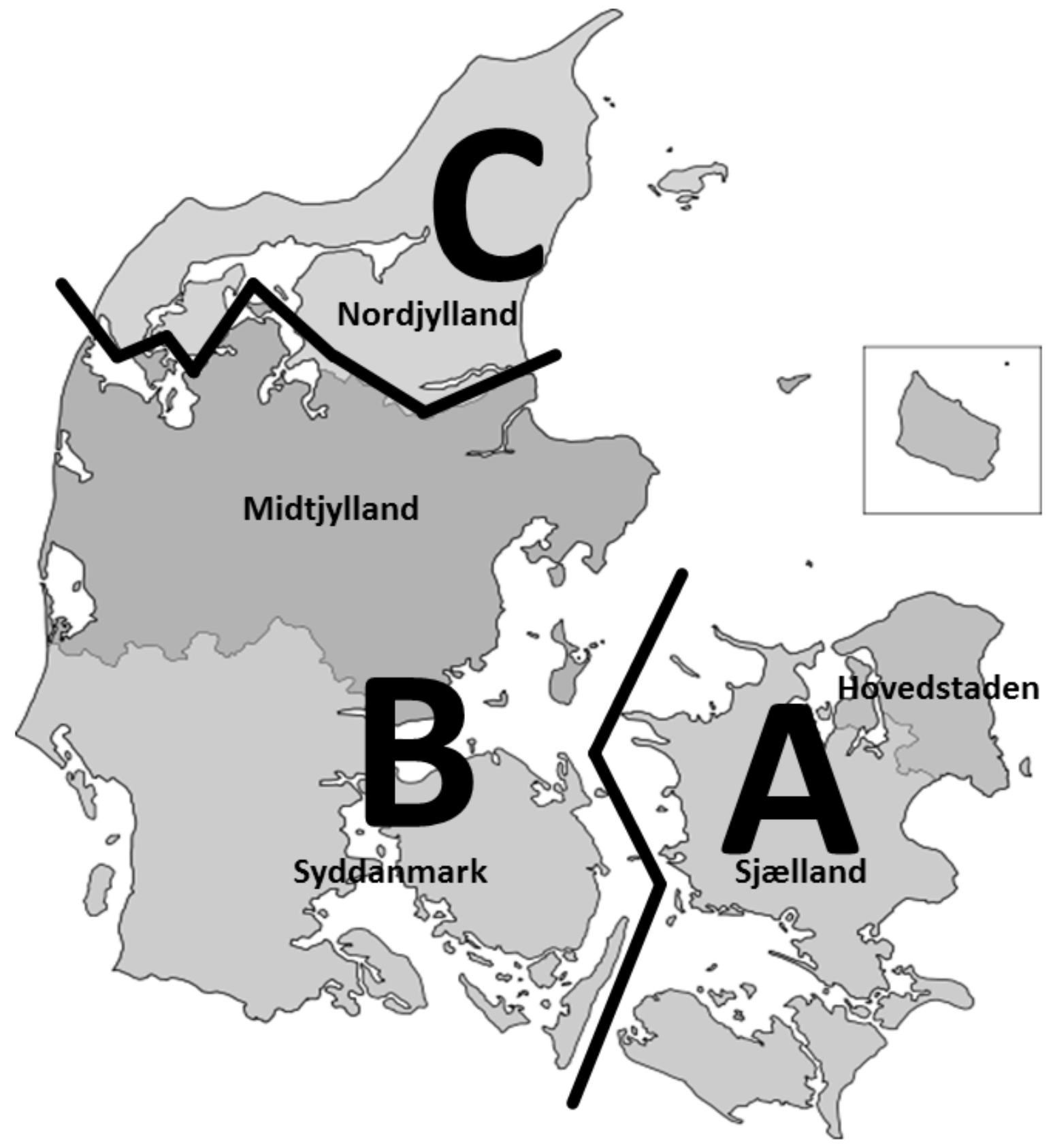

\begin{tabular}{|c|c|c|c|c|c|c|c|c|c|}
\hline \multicolumn{2}{|c|}{ Region } & \multirow{2}{*}{\multicolumn{2}{|c|}{$\begin{array}{l}\text { Population } \\
\qquad \% \text { of total }\end{array}$}} & \multicolumn{2}{|c|}{ Area } & \multicolumn{2}{|c|}{ Agricultural area } & \multirow{2}{*}{\multicolumn{2}{|c|}{$\begin{array}{l}\text { Livestock units } \\
\qquad \% \text { of tota }\end{array}$}} \\
\hline & & & & ha & $\%$ of total & ha & $\%$ of total & & \\
\hline \multirow{2}{*}{ A } & Sjælland & \multirow{2}{*}{$2,532,393$} & \multirow{2}{*}{$45 \%$} & \multirow{2}{*}{983,400} & \multirow{2}{*}{$23 \%$} & \multirow{2}{*}{558,203} & \multirow{2}{*}{$22 \%$} & \multirow{2}{*}{$3,208,452$} & \multirow{2}{*}{$11 \%$} \\
\hline & Hovedstaden & & & & & & & & \\
\hline \multirow[b]{2}{*}{ B } & Syddanmark & \multirow[b]{2}{*}{$2,468,024$} & \multirow[b]{2}{*}{$44 \%$} & \multirow[b]{2}{*}{$2,533,320$} & \multirow[b]{2}{*}{$59 \%$} & \multirow[b]{2}{*}{$1,537,864$} & \multirow[b]{2}{*}{$60 \%$} & \multirow[b]{2}{*}{$24,438,958$} & \multirow[b]{2}{*}{$65 \%$} \\
\hline & Midtjylland & & & & & & & & \\
\hline C & Nordjylland & 579,996 & $10 \%$ & 791,000 & $18 \%$ & 470,819 & $18 \%$ & $9,145,091$ & $24 \%$ \\
\hline \multicolumn{2}{|c|}{ DENMARK TOTAL } & $5,580,413$ & & $4,307,720$ & & $2,566,886$ & & $36,792,501$ & \\
\hline
\end{tabular}


Figure 1 System overview. Region designations used in this study are Region A:

2 Hovedstaden (incl. the island of Bornholm) \& Sjælland; region B: Midtjylland \& Syddanmark;

3 region C: Nordjylland. Livestock units are livestock normalized by excretion (of nitrogen) of

4 different types of livestock (Miljøministeriet 2010), used here as a proxy to show intensity of

5 animal production.

The differences between $\mathrm{P}$ flows are most pronounced between regions A and C. The two

8 administrative regions we denoted region B show a mix of the characteristics of $\mathrm{A}$ and $\mathrm{C}$ and

9 were combined in this analysis; the partly rural capital region was combined with region Sjælland

10 as region $\mathrm{A}$. The agricultural area of densely populated region $\mathrm{A}$ in the east is dominated by

11 arable crop production, whereas less densely populated region $\mathrm{C}$ is dominated by intensive

12 animal production, mainly dairy and pigs, with associated fodder crop production (Figure 1).

13 Region B is characterised by intensive animal production in the western part and a less intensive

14 animal production and more arable crop production in the eastern part, i.e. it is a mix of arable

15 crop and animal production (for data on livestock production and crop cultivation, see Statistics

16 Denmark (2013a; 2013 b; 2013g; 2013l, 2013r; 2013v)). The population density in region B also

17 is between that of $\mathrm{A}$ and $\mathrm{C}$.

18 The SFA model consists of a total of 51 processes and 166 flows, integrating the regional

19 and country scale in a single SFA system. On the national scale, the system of P flows and stocks

20 comprises the processes industry \& trade, consumption, wastewater treatment, agriculture \&

21 forestry, and waste management. Within the national scale model, the processes agriculture \&

22 forestry and waste management each comprise three more detailed regional sub-systems.

Industry \& trade is the process encompassing production, sales and distribution of P-

24 containing goods. Imports and exports are also routed through this process. The process 
1 consumption handles the end use of P-containing goods by individuals and public entities

2 including non-agricultural land, with food consumption, waste and wastewater production

3 dominating the turnover of this process. Wastewater, including industrial wastewater and

4 wastewater from cesspits of households not connected to public sewers, is handled in the process

5 wastewater treatment. Agricultural goods and products from forestry are produced in the process

6 agriculture \& forestry, which also includes management of animal manures. Waste management

7 comprises the processing and handling of solid waste (municipal and industrial solid waste,

8 compost, agricultural, and garden and park waste) as well as sewage sludge.

9 On the regional level, the process agriculture \& forestry consists of four sub-processes:

10 agricultural soil, crop production, animal production and biogas production. The term

11 agricultural soil here applies to the total agricultural area, grassland, and forestry area as

12 registered by Statistics Denmark (2013b; 2013s; 2013v). The main P inputs into this process are

13 mineral fertilisers and animal manure applied to land. Other inputs of fertilisers are the

14 application of compost, digestate, sewage sludge, and the re-application of crop residues (e.g.

15 straw). The biogas production process was placed in the agriculture \& forestry sub-system

16 (instead of waste management) since plants are predominantly owned by farmers or farmers'

17 cooperatives and closely linked to agriculture (Raven \& Gregersen 2005). The process comprises

18 farm-scale and joint (i.e. centralised plants receiving manure from more than one farm) biogas

19 plants receiving mainly manure and minor amounts of organic food processing waste (e.g. Raven

20 \& Gregersen 2005; Naturstyrelsen 2011; Birkmose et al. 2013). Minor inputs to soil unrelated to

21 fertilisation result from new seeds and planting material applied on fields, and atmospheric

22 deposition of $\mathrm{P}$ in dust, falling leaves, and bird faeces (EEA 2005). Changes in the annual P soil

23 stock are shown in this process. The process crop production covers agricultural crops as well as

24 forestry products, with P uptake by plants from the agricultural soil process as the main input of 
1 P; outputs are comprised of plant products, wood, feed and fodder for the animal production

2 process. The process animal production has as its output the animal products meat, including

3 animals sold or sent for slaughter, milk and eggs, as well as animal manure; the latter is, in terms

4 of $\mathrm{P}$, the main output of animal production. A minor amount of $\mathrm{P}$, in the form of manure and $\mathrm{P}$ -

5 rich wastes from industry, goes into farm-scale and joint agricultural biogas plants.

The process waste management consists of six sub-processes on the regional level, with

7 the main processes being sludge treatment, incineration, composting, and landfills \&

8 construction. The processes input organic waste and input solid waste are "virtual” processes for

9 layout and visualization purposes only, and route P flows from inputs of organic waste and other

10 solid waste to different treatment processes. We show the municipal solid waste (MSW) stream

11 divided into a biowaste and non-biowaste fraction to visualise the $\mathrm{P}$ potential in the former; for

12 the biowaste fraction of household waste we consider bio-waste as defined in the EU Waste

13 Framework Directive (European Parliament \& European Council 2008), mainly vegetable and

14 animal food waste with minor amounts of non-source-separated yard waste (Riber et al. 2009).

15 Apart from the majority of garden waste, at present this is not generally collected separately in

16 the Danish MSW management system. The recycling flow mostly comprises slaughterhouse

17 waste, such as processed meat and bone meal partly used as animal feed for the fur industry (see

18 Fødevarestyrelsen 2015). Sewage sludge from the wastewater treatment process is further

19 handled in the waste management process and the sludge treatment process in the regional waste

20 management sub-systems. The landfilled fractions of solid waste, as well as residues from

21 incineration of solid waste or sludge to be landfilled or reused in the construction sector, are

22 routed to the process landfill \& construction, with the annual accumulation (in landfills and

23 cement kilns) indicated. 


\subsection{Data sources and uncertainty assessment}

Official statistical data form the basis of this study; the main sources are Statistics

3 Denmark, the Danish Environmental Protection Agency (Miljøstyrelsen), the AgriFish Agency

4 (Naturerhvervstyrelsen), Nature Agency (Naturstyrelsen), Eurostat, the European Environment

5 Agency (EEA), and the Danish Food Composition Databank. Official reports from the Danish

6 authorities are drawn on as a supplement to statistical data. Scientific journal publications,

7 specific to Denmark where applicable, were used to establish and/or validate a number of more

8 specific flows. In individual cases, e.g. the nutrient yield from farm-scale biogas plants, data

9 reported from businesses or business associations were used. Data sources for individual flows

10 are listed in the supplementary information in Table A.1.

11 We used the uncertainty concept introduced by Hedbrant \& Sörme (2001), in their

12 quantification of urban metal stocks, to estimate uncertainties of P flows. We categorised data

13 sources typically available in a European country on the national and sub-national level (Table 1)

14 and ranked them according to their estimated reliability. Flows are assigned an uncertainty level

15 corresponding to an interval established by an "uncertainty factor", corresponding to the

16 representativeness and accuracy of the data source and resulting in an estimated uncertainty

17 range. Since this method produces increasingly asymmetrical intervals as uncertainty increases,

18 we furthermore used Laner et al.'s (2015) modification for use with the STAN software, to be

19 compatible with the normally distributed, symmetric intervals used in STAN. In this adaptation,

20 the uncertainty factors are converted into coefficients of variation (CV); normal distribution is

21 assumed in STAN. Laner et al. (2015) define the mean value multiplied with the uncertainty

22 factor as the mean value plus two standard deviations, with a symmetric interval around the mean

23 corresponding to a 95\% confidence interval. Table A.1 shows individual flows and the

24 uncertainty factors and coefficients of variation associated with them. Unless a data source listed 
1 the elementary P flows, this was done for both material (bulk) flows and P concentration to

2 calculate the uncertainty range of the P flow. While P concentrations of similar material flows

3 can vary across the country, we also assume countrywide average $\mathrm{P}$ concentrations for regional 4 flows.

5

Table 1 Uncertainty concept (based on Hedbrant \& Sörme 2000, Laner et al. 2015). We classify uncertainties in 5 levels, each level corresponding to a factor and a resulting coefficient

8 of variation (CV). A higher uncertainty level means less reliable data source, and a higher CV.

\begin{tabular}{cccl}
\hline Uncertainty level & Factor & CV & \multicolumn{1}{c}{ Source of information } \\
\hline 1 & 1.3 & $15.0 \%$ & $\begin{array}{l}\text { Official statistics on a national level for } 2011 \\
2\end{array}$ \\
1.6 & $30.0 \%$ & $\begin{array}{l}\text { Official statistics geographically up-/downscaled or temporal correlation } \pm 3 \\
\text { years }\end{array}$ \\
3 & 1.9 & $45.0 \%$ & Scientific literature \& technical reports \\
5 & 2.2 & $60.0 \%$ & Information published by businesses or plant operators \\
\hline
\end{tabular}

\section{9} result in an exponential increase of uncertainty ranges with increasing uncertainty levels, and

21 hence a large difference in uncertainty ranges between high and low uncertainty levels. There is 
1 little room for reconciliation of data with low uncertainty factors, and so reconciliation is

2 concentrated on the few data with the highest uncertainties. We opted for a "flatter" distribution

3 between low and high uncertainty ranges (Table 1) so as to allow for more distributed data

4 reconciliation throughout the system.

5

6 3. RESULTS \& DISCUSSION

8 3.1. Results

10 3.1.1. Data uncertainty and data reconciliation

11 Data reconciliation in STAN resulted in a mean deviation of reconciled from entered

12 values of 9\%. Flows showing large deviations from input to reconciled values were concentrated

13 around the Industry \& trade process; this is due to comparatively high uncertainty regarding

14 imported, exported and domestically traded non-food products. Conversely, standard deviations

15 of flow values were reduced overall by $40 \%$ as a result of data reconciliation. In the following,

16 we report flow values as shown in the reconciled STAN model.

17

18 3.1.2. Countrywide phosphorus flows and stocks

19 Figure 2 shows the P flows in Denmark, on the national scale with flows reported in Gg P 20 per year, for the base year 2011. 


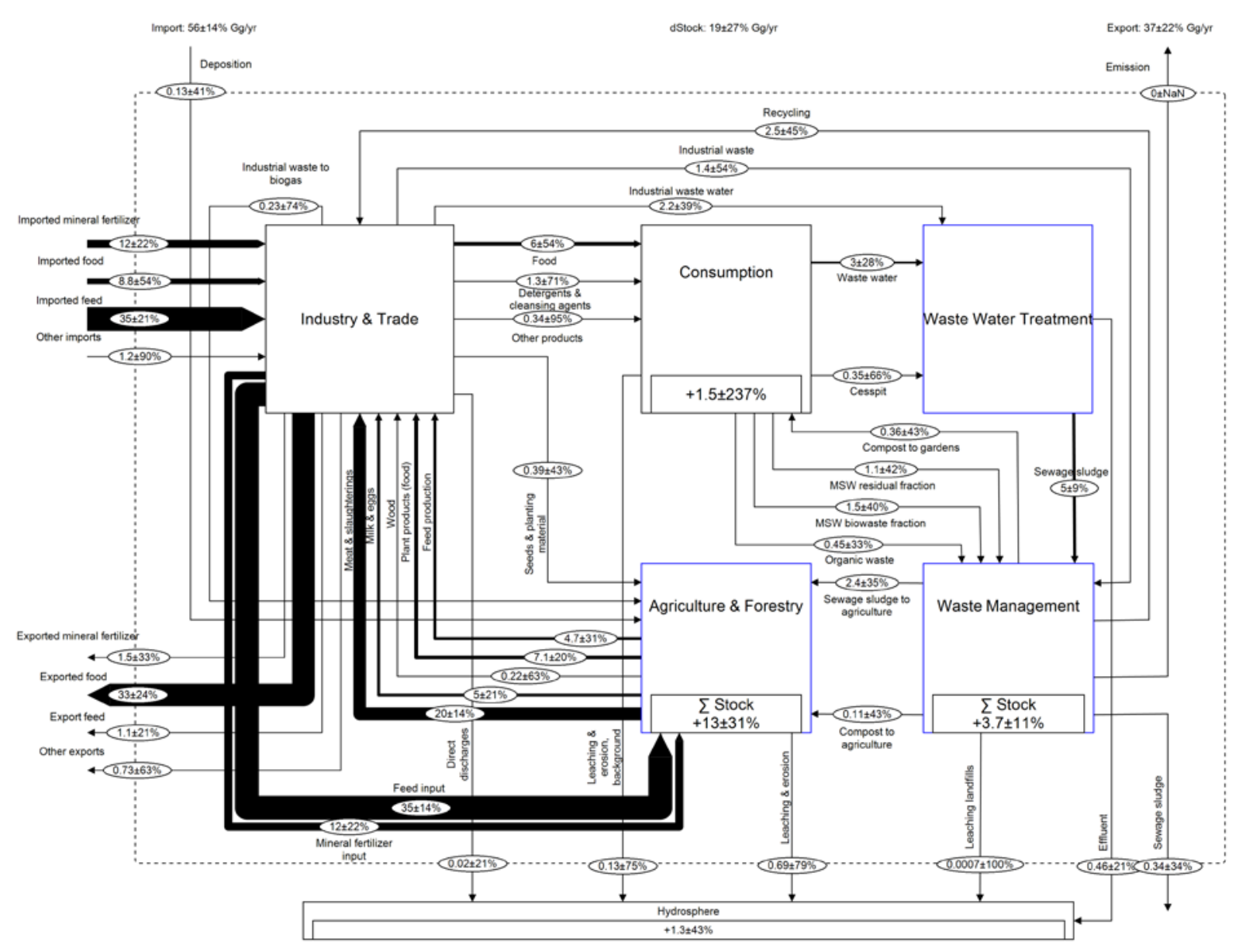

Figure 2 Phosphorus (P) flows [Gg yr ${ }^{-1}$ ] in Denmark for the base year 2011, on the

3 national scale. Values are shown after data reconciliation. Arrows denote (substance) flows of P,

4 with flow values and relative uncertainties in oval shapes. Dashed line denotes system boundary.

5 Stock changes shown in boxes inside processes where applicable. Relative uncertainty (\%)

6 shown for each flow.

7

8 The total P inflow to Denmark was about $56 \mathrm{Gg} \mathrm{yr}^{-1}$, while the total outflow was $37 \mathrm{Gg}$

$9 \mathrm{yr}^{-1}$. The surplus, of approximately $19 \mathrm{Gg} \mathrm{yr}^{-1}$, accumulates within the system. The main P import

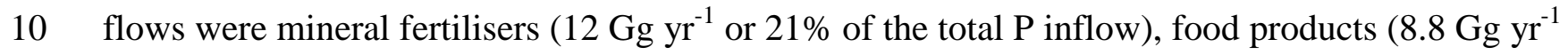

11 or $16 \%$ of total inflow) and feedstuffs (35 $\mathrm{Gg} \mathrm{yr}^{-1}$ or $63 \%$ of total inflow). Food products (33 Gg 
$1 \mathrm{yr}^{-1}$ or $59 \%$ total P outflow) form the largest P export. A significant part of the P that entered

2 Denmark in 2011 remained within the system (34\% of total P inflow) primarily as addition to

3 stocks in agricultural soils (13 $\mathrm{Gg} \mathrm{yr}^{-1}$ or $68 \%$ of total stock increase), in the waste management

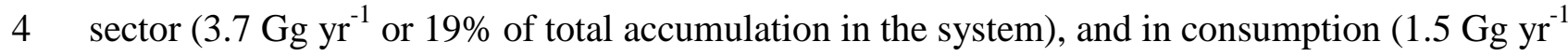

5 or $8 \%$ of annual accumulation). A major reason for the relatively high $\mathrm{P}$ build-up in households is

6 likely to be home composting in private gardens, as well as fertiliser used on public and private

7 non-agricultural land. Pet excreta are another part of this accumulation; however, the P quantities

8 in pet excreta ending on land, or in waste and wastewater management, could not be clearly

9 determined and traced. Three times the amount of P from compost is applied to private and public

10 gardens $\left(0.36 \mathrm{Gg} \mathrm{yr}^{-1}\right)$ than to agricultural land $\left(0.11 \mathrm{Gg} \mathrm{yr}^{-1}\right)$. Losses to the hydrosphere are

11 relatively small, at $1.3 \mathrm{Gg} \mathrm{yr}^{-1}$, or $2 \%$ of total annual inflows into the system, in line with the

12 decreasing trend shown since 1985 by EEA (2005). As is common in SFA studies of P, the

13 largest turnover of $\mathrm{P}$ within the system comprises exchanges between the industry \& trade and

14 agriculture \& forestry processes, with aggregated flows more than one order of magnitude larger

15 than other flows on the national level. Within the agriculture process, manure flows are of a

16 similar magnitude, with a countrywide total of $23 \mathrm{Gg} \mathrm{yr}^{-1}$. The most relevant internal flows occur

17 between industry and agriculture, with the largest flows from industry and trade to agriculture

18 being feed (35 $\mathrm{Gg} \mathrm{yr}^{-1}$ ) and fertiliser (12 $\mathrm{Gg} \mathrm{yr}^{-1}$ ), and the largest flow from agriculture to

19 industry and trade being food products (32 $\left.\mathrm{Gg} \mathrm{yr}^{-1}\right)$.

20 Denmark relies on import of P fertiliser as the country has no reserves of phosphate rock.

21 The largest part of the P inflow, however, occurs via feedstuff import to support intensive animal

22 production. A significant proportion of $\mathrm{P}$ in the feedstuff is excreted in the manure from Danish

23 animal husbandry (in total $23.2 \mathrm{Gg} \mathrm{yr}^{-1}$ ), which is used to fertilise the agricultural soils where it is

24 a main contributor to the build-up of P stocks in the agriculture \& forestry process. The amount 
1 of P re-used within the system from the consumption, wastewater treatment and waste

2 management processes, in the form of compost, fishmeal and slaughterhouse waste, and sewage

3 sludge or products thereof, amounts to only approximately $5.4 \mathrm{Gg} \mathrm{yr}^{-1}$. This corresponds to about

$410 \%$ of the annual P inflow, or $36 \%$ of inflows to waste management and wastewater treatment.

5 Figure 3 shows the accumulation of $\mathrm{P}$ in the system as a ratio of total inflows into the system,

6 divided between regions where applicable.

7

8

15

3

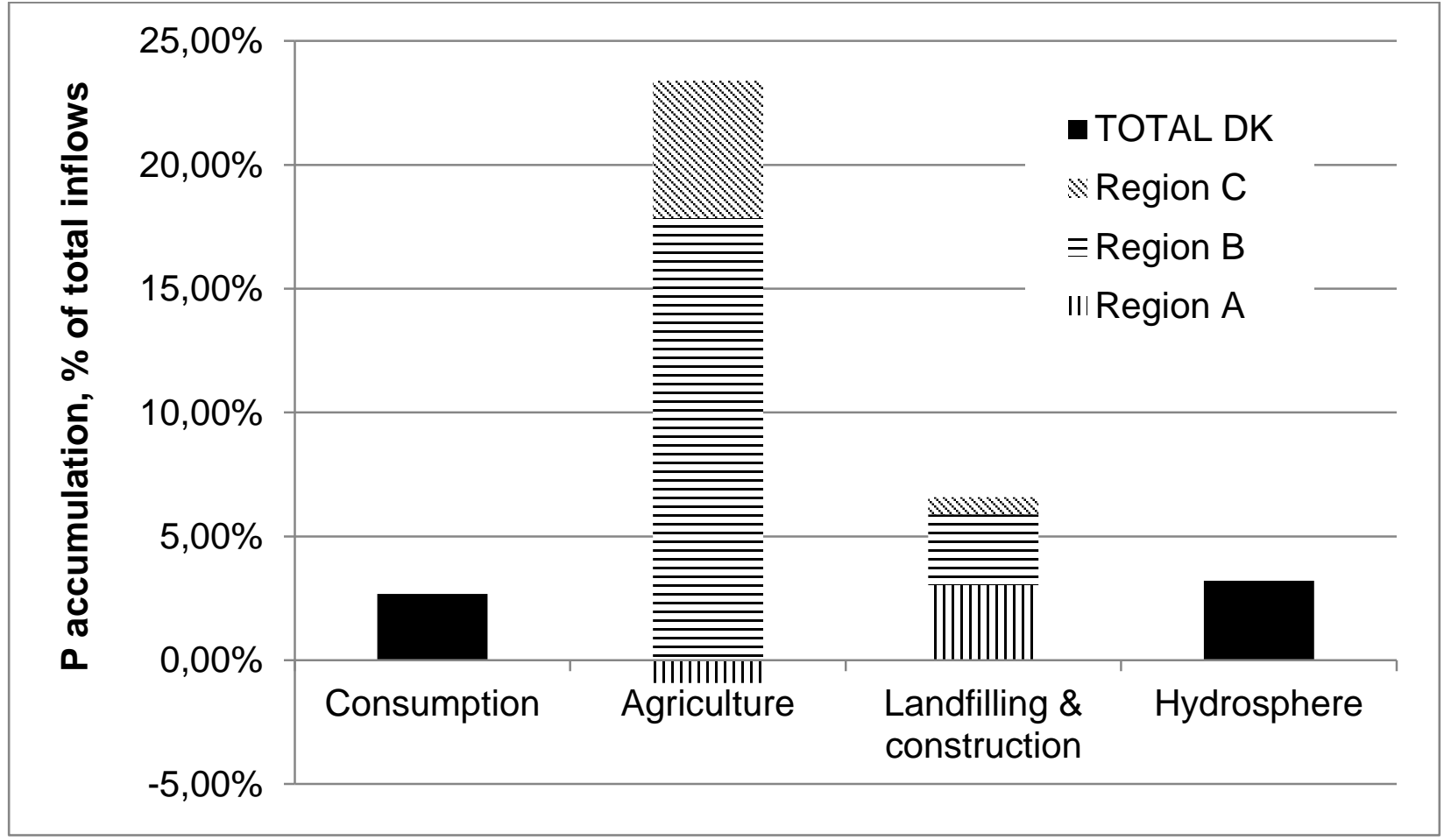

Figure 3 Phosphorus (P) accumulation and losses in the system, \% of total inflows to system boundary of this study. The large share of region B is due to its much larger area compared to A and C. Region A shows a slight P deficit in agricultural soils. As Figure 3 highlights, most $\mathrm{P}$ inflows accumulate in agricultural soil $\left(13 \mathrm{Gg} \mathrm{yr}^{-1}\right)$. The main contributor to this process is the feedstuffs inflow at $35 \mathrm{Gg} \mathrm{yr}^{-1}$, and, consequently, the 
1 production of animal manure applied to the fields at rates in excess of plant removal. On the

2 country scale, high rates of $\mathrm{P}$ accumulation correspond to high numbers of farm animals and

3 hence manure production; fertiliser imports for crop production are less important except for

4 region $\mathrm{A}$, where fertiliser $\mathrm{P}$ input exceeds manure $\mathrm{P}$. Region $\mathrm{A}$ is the only region with a slight soil

5 P deficit (-0.91 $\left.\mathrm{kg} \mathrm{ha}^{-1} \mathrm{yr}^{-1}\right)$. The high contribution of region $\mathrm{B}$ to the $\mathrm{P}$ accumulation in

6 agriculture (10), is due to its larger area (see Figure 1) and mix of animal husbandry and crop

7 production. In the waste management system, $\mathrm{P}$ accumulates in the form of landfilled wastes

8 (mainly incineration slag and ash), and waste and ash used in cement kilns, and hence in

9 construction; regional differences here are mainly owing to population and industrial density. It is

10 notable that the accumulation in this sector is, across the country, larger than the accumulation of

$11 \quad \mathrm{P}$ in consumption.

12

\section{3.1.3. Regional consideration of phosphorus flows and stocks}

\section{$15 \quad$ 3.1.3.1. Agriculture}

16 Figures 4 a, b and c show the P stocks and flows of the agricultural systems of Denmark, 17 in absolute amounts of Gg P per year, divided in three regions. Table 2 gives these data for 2011

18 in absolute values, in kg P per ha of agricultural land, and kg per capita to allow a comparison of

19 P housekeeping (e.g. intensity of P use and recovery). 


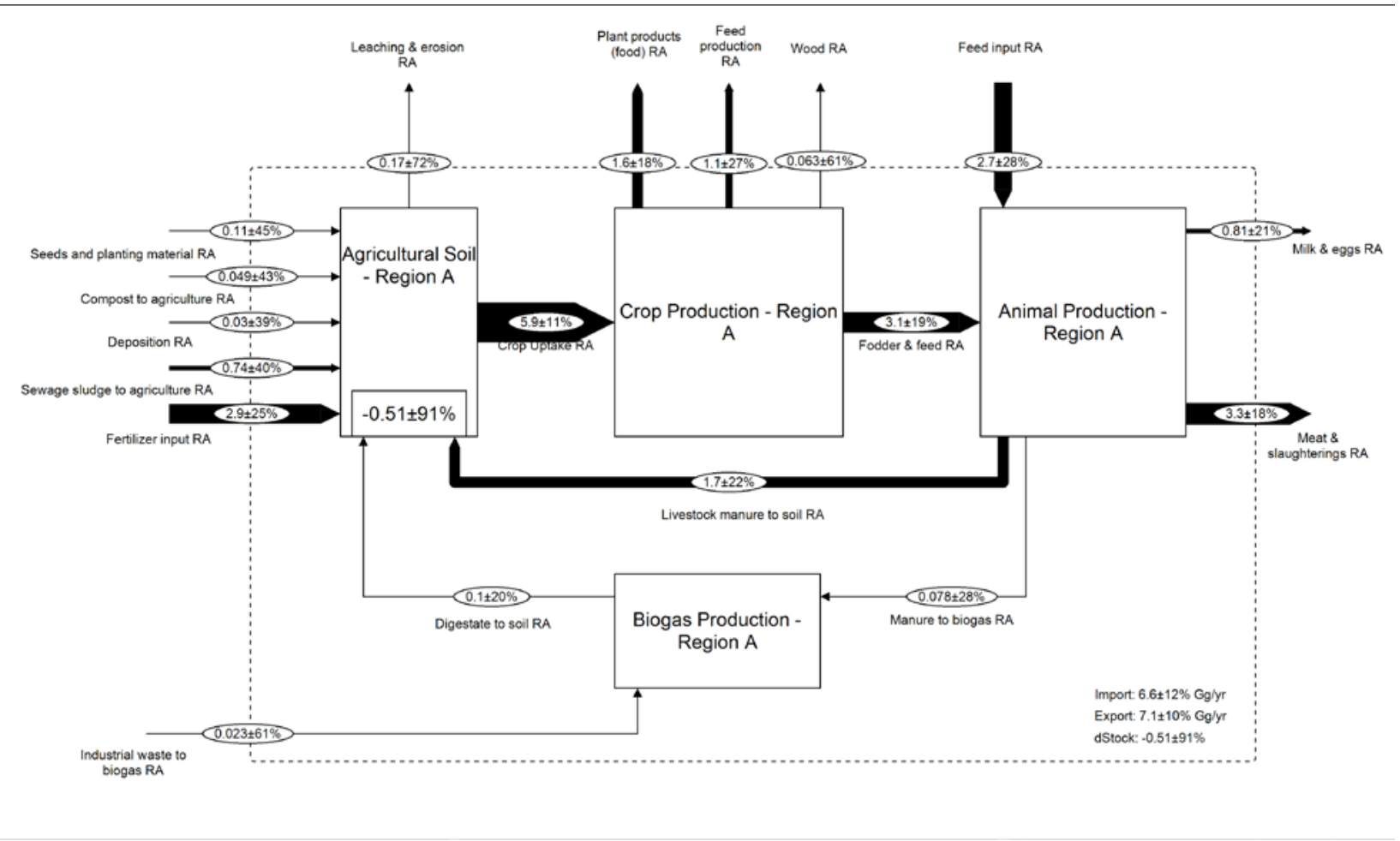

Figure $4 a$

3

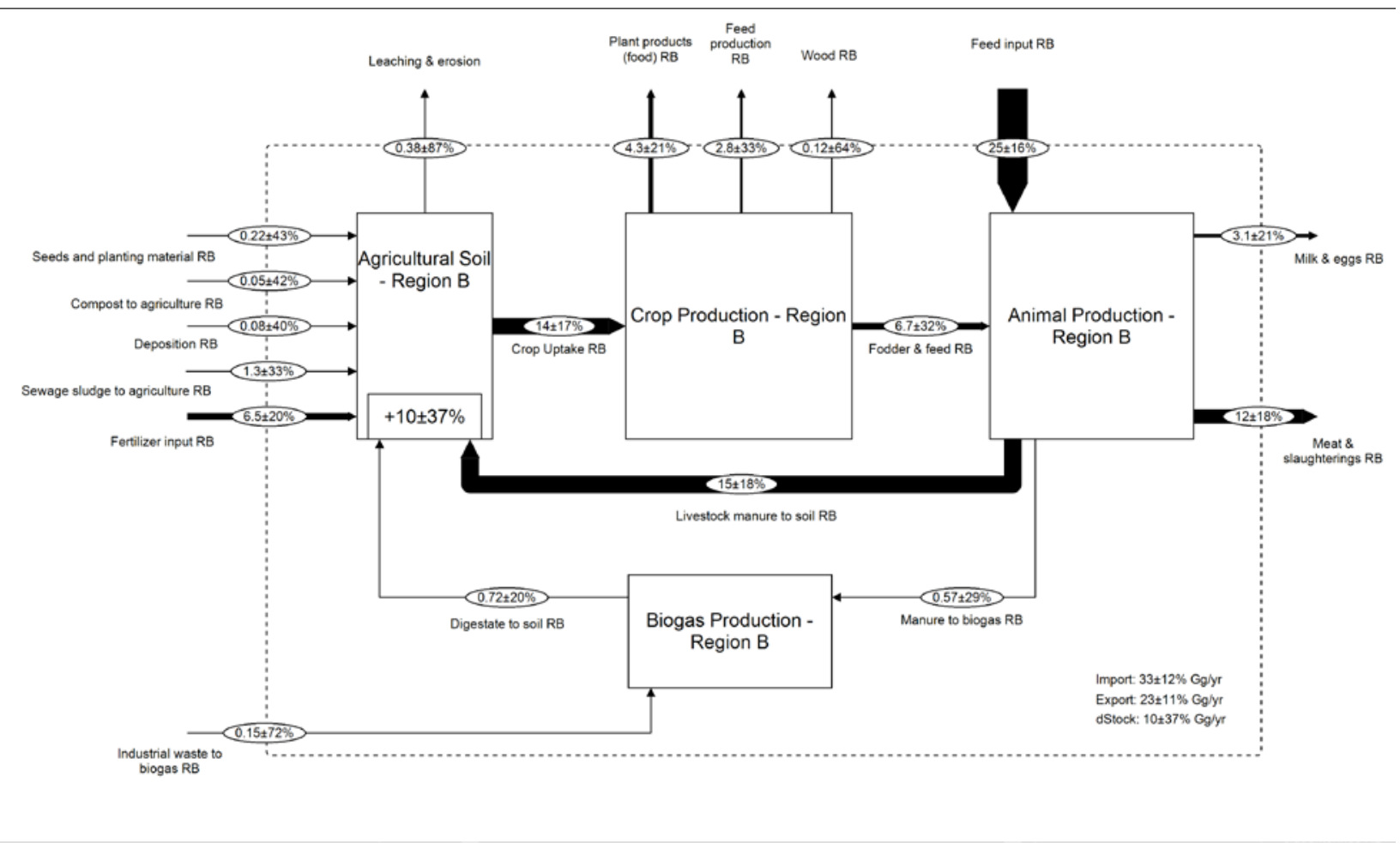




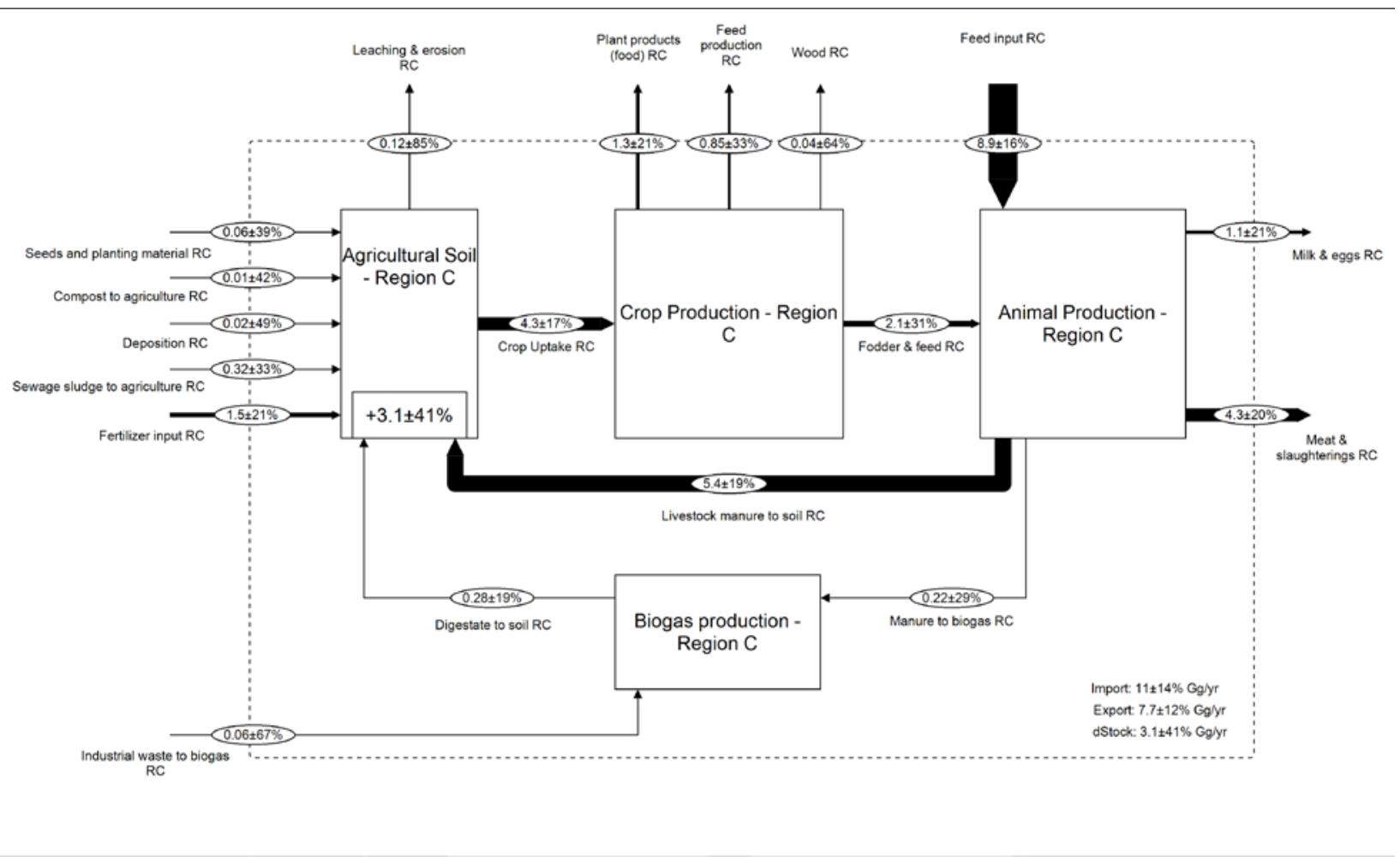

Figure $4 c$

Figure $4 a, b, c$ Phosphorus (P) flows in agriculture on a regional scale, given in $\mathrm{Gg} \mathrm{P} \mathrm{yr}^{-}$

$6 \quad$. Values shown after data reconciliation. Regions A, B, C abbreviated as RA, RB, RC in flow

names.

8

9 Table 2 Reconciled flow values of P (from top to bottom: input flows/flows within the 10 agricultural system/output flows) for the agriculture sub-system, by region (2011).

\begin{tabular}{|c|c|c|c|c|c|c|c|c|c|c|}
\hline & & {$\left[G g y r^{-1}\right]$} & $\begin{array}{r}\text { Region A } \\
{\left[k g h a^{-1}\right.} \\
\left.y r^{-1}\right]\end{array}$ & $\begin{array}{r}{\left[k g \operatorname{cap}^{-1}\right.} \\
\left.y r^{-1}\right]\end{array}$ & {$\left[G g y r^{-1}\right]$} & $\begin{array}{c}\text { Region B } \\
{\left[\begin{array}{c}\mathrm{kg} \mathrm{ha}^{-1} \\
\left.\mathrm{yr}^{-1}\right]\end{array}\right.}\end{array}$ & $\begin{array}{r}{\left[k g c^{c a p} p^{-1}\right.} \\
\left.y r^{-1}\right]\end{array}$ & {$\left[G g y r^{-1}\right]$} & 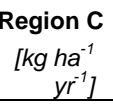 & $\begin{array}{r}{\left[\mathrm{kg} \mathrm{cap} p^{-1}\right.} \\
\left.y r^{-1}\right]\end{array}$ \\
\hline \multirow{7}{*}{ 竞 } & Deposition & 0.03 & 0.05 & 0.01 & 0.08 & 0.05 & 0.03 & 0.02 & 0.04 & 0.03 \\
\hline & Compost to agriculture & 0.05 & 0.09 & 0.02 & 0.05 & 0.03 & 0.02 & 0.01 & 0.02 & 0.02 \\
\hline & Seeds \& planting material & 0.11 & 0.19 & 0.04 & 0.22 & 0.14 & 0.09 & 0.06 & 0.13 & 0.10 \\
\hline & Sewage sludge to agriculture & 0.74 & 1.33 & 0.29 & 1.34 & 0.87 & 0.54 & 0.32 & 0.68 & 0.55 \\
\hline & Industrial waste to biogas & 0.02 & 0.04 & 0.01 & 0.15 & 0.10 & 0.06 & 0.06 & 0.13 & 0.10 \\
\hline & Fertilizer input & 2.88 & 5.16 & 1.14 & 6.50 & 4.22 & 2.63 & 1.46 & 3.10 & 2.52 \\
\hline & Feed input & 2.73 & 4.89 & 1.08 & 24.55 & 15.96 & 9.95 & 8.94 & 18.99 & 15.41 \\
\hline & Crop uptake & 5.92 & 10.60 & 2.34 & 13.87 & 9.02 & 5.62 & 4.27 & 9.07 & 7.36 \\
\hline
\end{tabular}




\begin{tabular}{|c|c|c|c|c|c|c|c|c|c|c|}
\hline & Fodder \& feed & 3.12 & 5.58 & 1.23 & 6.65 & 4.33 & 2.70 & 2.10 & 4.46 & 3.62 \\
\hline & Livestock manure to soil & 1.66 & 2.98 & 0.66 & 15.30 & 9.95 & 6.20 & 5.37 & 11.41 & 9.26 \\
\hline & Manure to biogas & 0.08 & 0.14 & 0.03 & 0.57 & 0.37 & 0.23 & 0.22 & 0.47 & 0.38 \\
\hline \multirow{7}{*}{$\begin{array}{l}\text { 를 } \\
\text { ํㅡㄹ } \\
0\end{array}$} & Leaching \& erosion & 0.17 & 0.30 & 0.07 & 0.38 & 0.24 & 0.15 & 0.12 & 0.25 & 0.20 \\
\hline & Feed production & 1.12 & 2.02 & 0.44 & 2.81 & 1.83 & 1.14 & 0.85 & 1.80 & 1.46 \\
\hline & Milk \& eggs & 0.81 & 1.45 & 0.32 & 3.10 & 2.01 & 1.25 & 1.10 & 2.34 & 1.90 \\
\hline & Meat \& slaughterings & 3.30 & 5.91 & 1.30 & 12.24 & 7.96 & 4.96 & 4.34 & 9.23 & 7.49 \\
\hline & Plant products (food) & 1.61 & 2.89 & 0.64 & 4.28 & 2.78 & 1.74 & 1.29 & 2.73 & 2.22 \\
\hline & Wood & 0.06 & 0.11 & 0.02 & 0.12 & 0.08 & 0.05 & 0.04 & 0.09 & 0.07 \\
\hline & Balance & -0.51 & -0.91 & -0.20 & 10.00 & 6.50 & 4.05 & 3.10 & 6.58 & 5.34 \\
\hline
\end{tabular}

1

2 The P flows per hectare and per year illustrate the differences between region A (higher

3 proportion of crop production) and region C (distinctly higher proportion of animal husbandry

4 and relatively low crop production) in this study. Region B combines both crop and animal

5 production; the latter sets it apart from crop-dominated region A. 


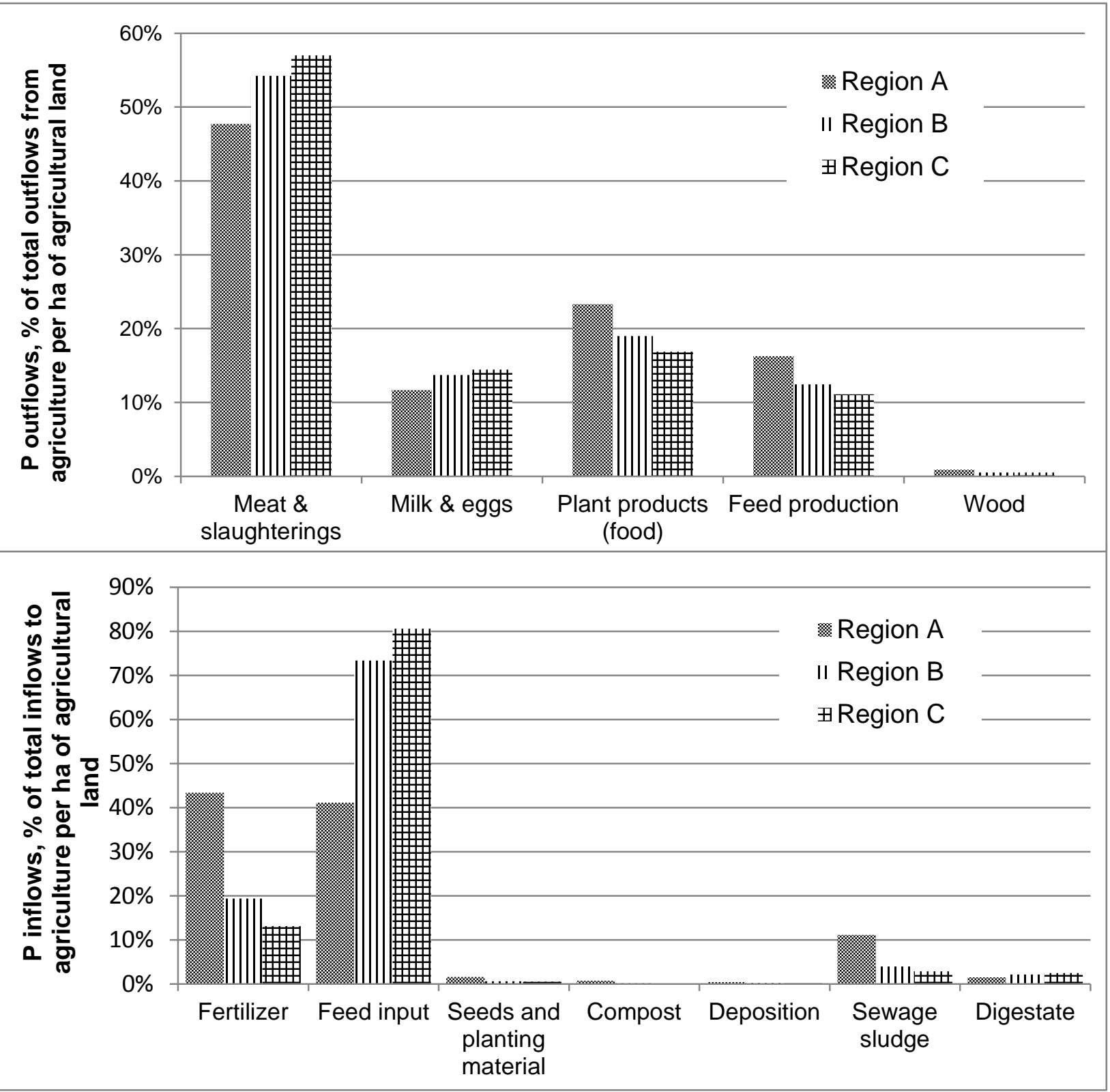

Figure 5 Phosphorus (P) inflows and outflows per ha of agricultural land, \% of total in-

3 and outflows, to/from the process agriculture.

4

$5 \quad$ Figure 5 shows the individual regional in- and outflows to and from agriculture in relation

6 to total regional in- and outflows, per hectare of agricultural land. Feedstuff imports are the main

7 drivers of regional $\mathrm{P}$ balances in regions $\mathrm{B}$ and $\mathrm{C}$, with fertiliser being the main input only in

8 region $\mathrm{A}$. In region $\mathrm{A}$, the main inflow is mineral fertiliser, at $5.2 \mathrm{~kg} \mathrm{ha}^{-1} \mathrm{yr}^{-1}$ of agricultural land 
1 (2.9 $\left.\mathrm{Gg} \mathrm{yr}^{-1}\right)$ or $44 \%$ of the total regional $\mathrm{P}$ inflow, with an inflow of feedstuffs of $4.9 \mathrm{~kg} \mathrm{ha}^{-1} \mathrm{yr}^{-1}$

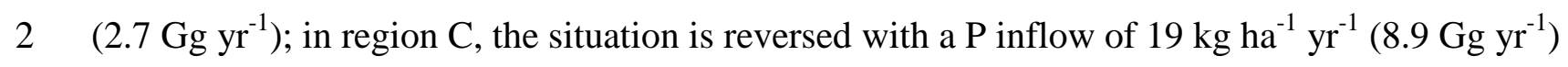

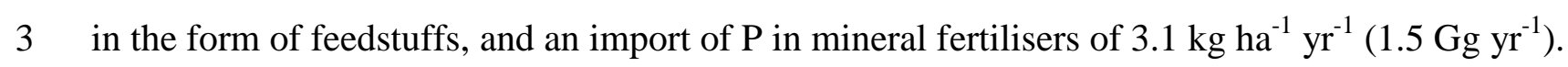

4 Region A shows the highest portion of plant products, feed materials, and wood in overall P

5 outflows at $5 \mathrm{~kg} \mathrm{ha}^{-1} \mathrm{yr}^{-1}\left(2.8 \mathrm{Gg} \mathrm{yr}^{-1}\right)$, whereas animal products dominate even more clearly in

6 regions $\mathrm{B}\left(10 \mathrm{~kg} \mathrm{ha}^{-1} \mathrm{yr}^{-1} ; 15.3 \mathrm{Gg} \mathrm{yr}^{-1}\right)$ and C (11.6 $\left.\mathrm{kg} \mathrm{ha}^{-1} \mathrm{yr}^{-1} ; 5.4 \mathrm{Gg} \mathrm{yr}^{-1}\right)$; for the entire

7 country, animal products form the main outflow. The output of manure from the animal

8 production process generally stays quite local, within the respective region ( Rubæk et al. 2013;

9 Sørensen et al. 2013). As the substance flow diagrams also highlight, nutrient quantity in manure

10 holds the most salient potential for fertiliser substitution, although these limitations in transport

11 currently hinder the most efficient use of manure $\mathrm{P}$ on agricultural land. $\mathrm{P}$ flows to from farm-

12 scale and joint farm-scale biogas plants, mainly supplied with manure, amount from 3\% (region

13 A) and 9\% (region B), to 15\% (region C) of mineral fertiliser P inputs in the respective region.

14 Assuming a 1:1 substitution of mineral fertiliser P by e.g. manure or digestate is a

15 simplification; in reality, P bioavailability to plants varies between different fertiliser products.

$16100 \%$ recycling is likewise a thermodynamic impossibility; the sizes of P flows are therefore

17 theoretical upper values with regard to recovery.

18 On a per hectare basis, $\mathrm{P}$ budgets of agricultural soil are similar and distinctly positive in

19 regions $\mathrm{B}$ and $\mathrm{C}$, with soil P stock build ups in region $\mathrm{B}$ of $6.5 \mathrm{~kg} \mathrm{ha}^{-1} \mathrm{yr}^{-1}\left(10 \mathrm{Gg} \mathrm{yr}^{-1}\right)$, and 6.6

$20 \mathrm{~kg} \mathrm{ha}^{-1} \mathrm{yr}^{-1}\left(3.1 \mathrm{Gg} \mathrm{yr}^{-1}\right)$ in region C. Region A shows a slight deficit at $-0.9 \mathrm{~kg} \mathrm{ha}^{-1} \mathrm{yr}^{-1}(-0.5 \mathrm{Gg}$

$21 \mathrm{yr}^{-1}$ ). The P nutrient use efficiency (the ratio of crop uptake to P inflow into agricultural soil)

22 ranges from 0.77 in region $\mathrm{A}$ to 0.80 and 0.74 in regions $\mathrm{B}$ and $\mathrm{C}$, respectively.

The differences between the regions stem from a historical concentration of crop

24 production without associated livestock in the eastern part of the country (Sjælland, Fyn, south- 
eastern Jutland; i.e. region A and part of region B in this study). This area is characterised by

2 more loamy and clayey soils with higher crop yield potentials. Livestock production in the past

3 30-40 years has become more concentrated in the south-western, western, and northern parts of

4 the country (Jutland; region C and part of B), characterised by sandy soils (Rubæk et al. 2013).

5 Specialisation in farming has driven the differentiation in agricultural production systems,

6 resulting in the differences in P loads associated with either crop or animal production (Rubæk et

$7 \quad$ al. 2013; Sibbesen \& Runge-Metzger 1992) as shown in this study.

\section{$9 \quad$ 3.1.3.2. Waste management}

10 The waste management sub-systems for the three regions are shown in Figure 6 a to c.

11 Table 3 shows these flows in absolute values and kg per capita for 2011. Regional differences in

12 waste management are mainly owing to differences in population, with minor differences also

13 due to the amount of industrial waste generated. Sewage sludge constitutes the main inflow of $\mathrm{P}$

14 in each region, with $\mathrm{P}$ flows an order of magnitude larger than other individual inflows to the

15 waste management subsystem; sludge inflows are very similar at $2 \mathrm{Gg} \mathrm{yr}^{-1}$ in region A and B

16 with similarly sized populations, and $0.5 \mathrm{Gg} \mathrm{yr}^{-1}$ in region C (approximately $0.8 \mathrm{~kg} \mathrm{cap}^{-1} \mathrm{yr}^{-1} \mathrm{in}$

17 each region). The $\mathrm{P}$ inflow of MSW amounts to about half of the $\mathrm{P}$ in sewage sludge in each

18 region. Since household bio-waste (apart from garden waste) is generally not collected

19 separately, the two separate flows pertaining to MSW in each region are merely illustrative; the

20 inflows of $\mathrm{P}$ from the biowaste fraction of MSW is approximately a third of the inflow of P from

21 sewage sludge. The recycling flow mostly comprises slaughterhouse waste, fishmeal and

22 processed meat and bone meal to be rendered or partly used as animal feed for the fur industry

23 (Fødevarestyrelsen 2015). 


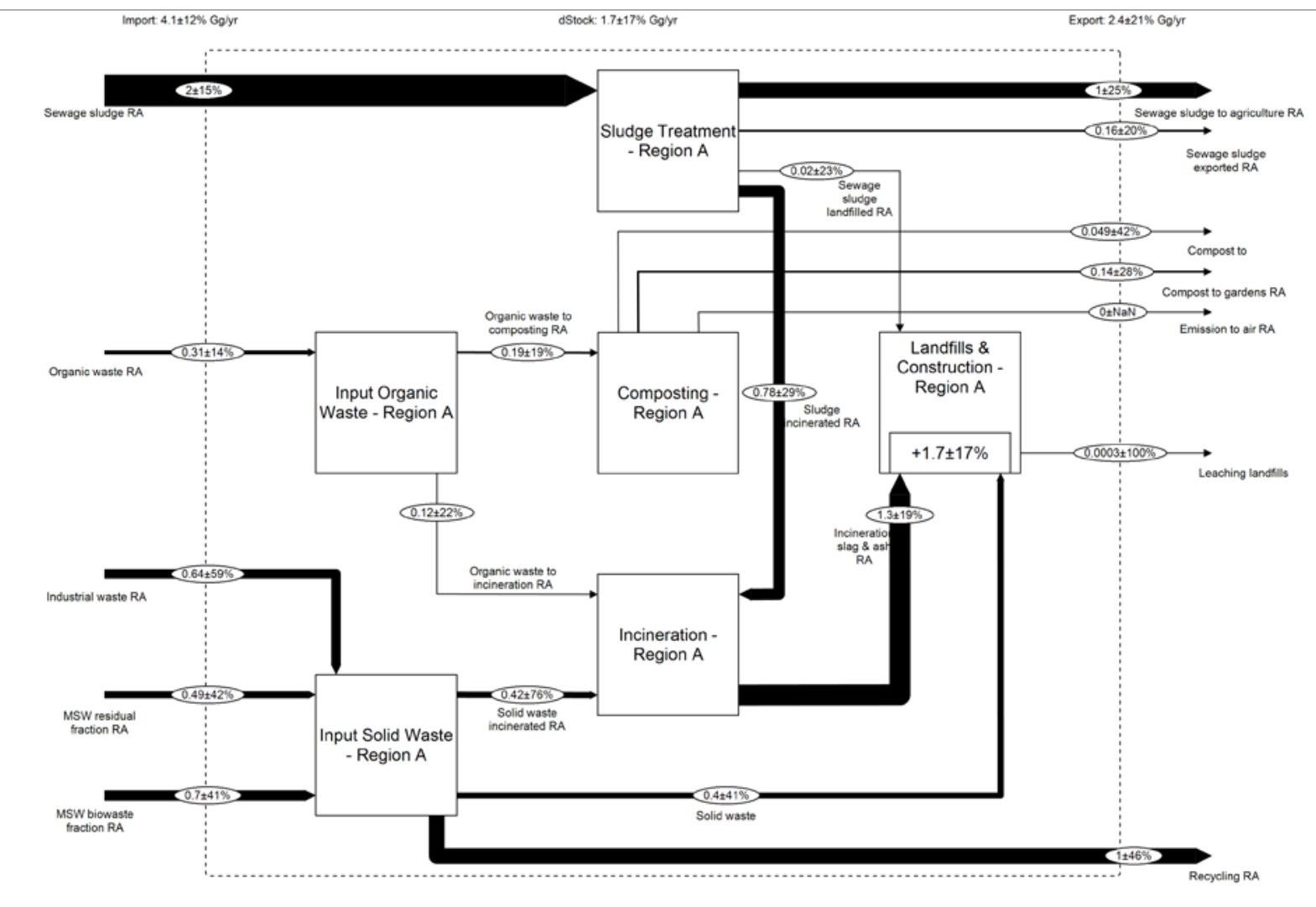

Figure $6 a$ 


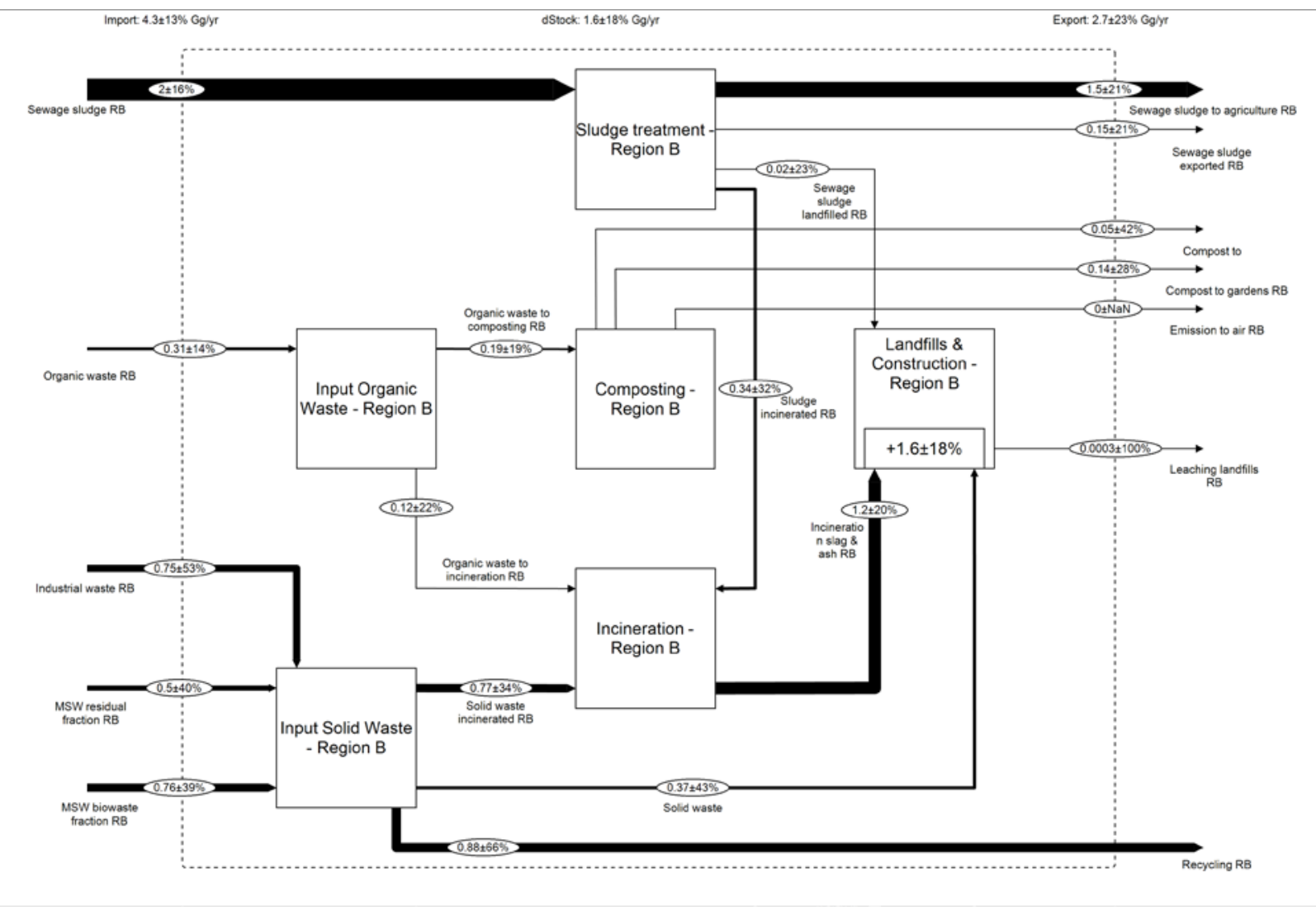

Figure $6 b$ 


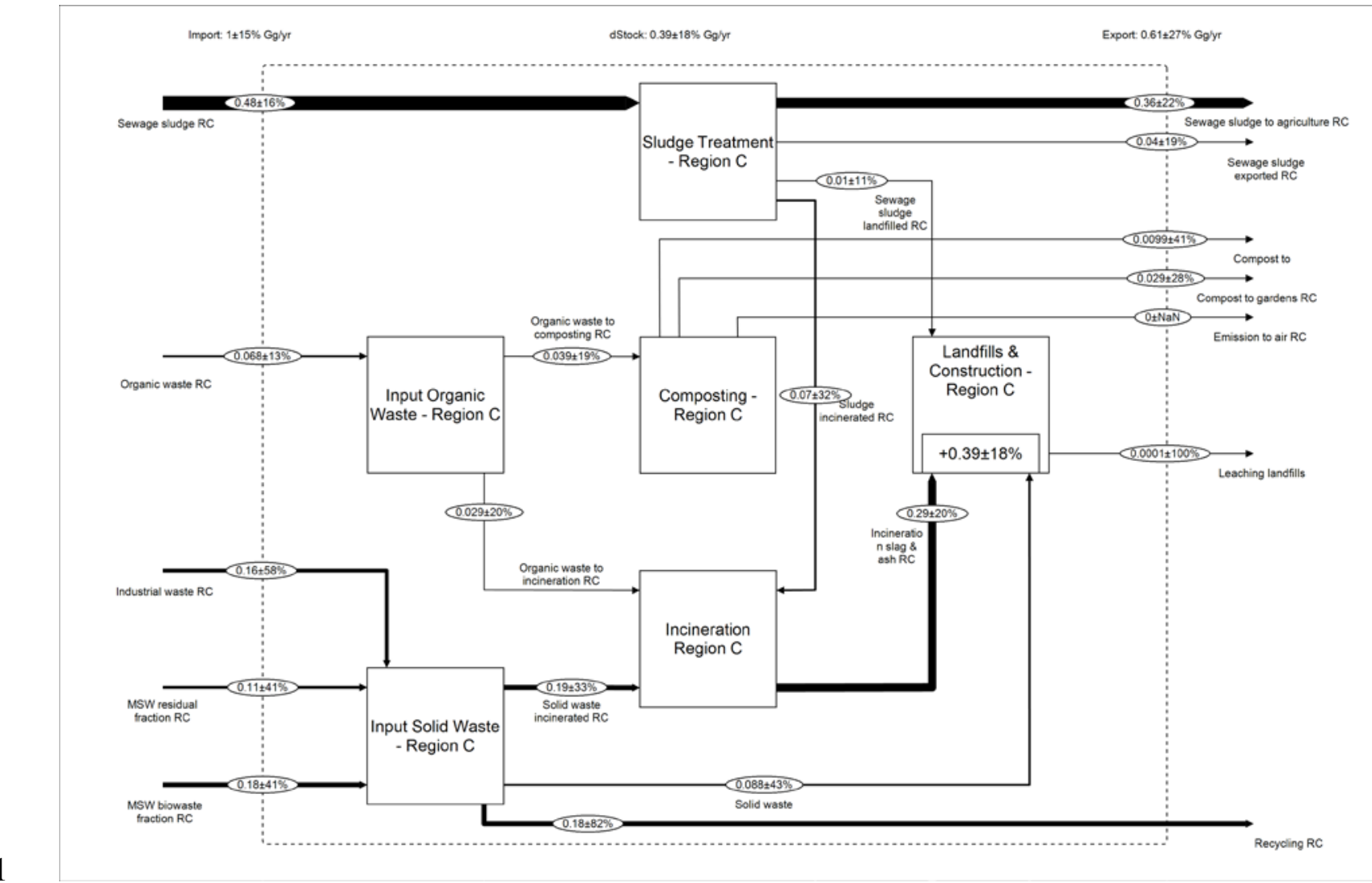

Figure 6c

Figure $6 a, b, c$ Phosphorus (P) flows in waste management on a regional scale, given in

$5 \mathrm{Gg} \mathrm{P} \mathrm{yr}{ }^{-1}$. Values shown after data reconciliation. Regions A, B, C abbreviated as RA, RB, RC in

6 flow names.

8 Table 3 Reconciled flow values of $\mathrm{P}$ for the waste management sub-system (from top to 9 bottom: input flows/flows within the waste management system/output flows), by region (2011).

\begin{tabular}{|c|c|c|c|c|c|c|c|}
\hline & & \multicolumn{2}{|c|}{ Region A } & \multicolumn{2}{|c|}{ Region B } & \multicolumn{2}{|c|}{ Region C } \\
\hline & & {$\left[G g y r^{-1}\right]$} & {$\left[\mathrm{kg} \mathrm{cap}^{-1} \mathrm{yr}^{-1}\right]$} & {$\left[G g y r^{-1}\right]$} & {$\left[k g \operatorname{cap}^{-1} y r^{-1}\right]$} & {$\left[G g y r^{-1}\right]$} & {$\left[k g \operatorname{cap}^{-1} y r^{-1}\right]$} \\
\hline \multirow{5}{*}{ 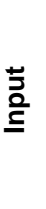 } & MSW residual fraction & 0.49 & 0.19 & 0.50 & 0.20 & 0.11 & 0.19 \\
\hline & MSW biowaste fraction & 0.70 & 0.28 & 0.76 & 0.31 & 0.18 & 0.31 \\
\hline & Sewage sludge & 1.99 & 0.79 & 2.02 & 0.82 & 0.48 & 0.82 \\
\hline & Organic waste & 0.31 & 0.12 & 0.31 & 0.12 & 0.07 & 0.12 \\
\hline & Industrial solid waste & 0.64 & 0.25 & 0.75 & 0.30 & 0.16 & 0.28 \\
\hline & Organic waste to composting & 0.19 & 0.08 & 0.19 & 0.08 & 0.04 & 0.07 \\
\hline & Organic waste to incineration & 0.12 & 0.05 & 0.12 & 0.05 & 0.03 & 0.05 \\
\hline & Solid waste incinerated & 0.42 & 0.17 & 0.77 & 0.31 & 0.19 & 0.32 \\
\hline
\end{tabular}




\begin{tabular}{|c|c|c|c|c|c|c|c|}
\hline & Solid waste landfilled & 0.40 & 0.16 & 0.37 & 0.15 & 0.09 & 0.15 \\
\hline & Sewage sludge landfilled & 0.02 & 0.008 & 0.02 & 0.01 & 0.01 & 0.02 \\
\hline & Sludge incinerated & 0.78 & 0.31 & 0.34 & 0.14 & 0.07 & 0.12 \\
\hline & Incineration slag \& ash & 1.31 & 0.52 & 1.22 & 0.49 & 0.29 & 0.50 \\
\hline \multirow{8}{*}{ 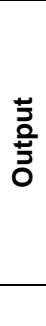 } & Recycling & 1.01 & 0.40 & 0.88 & 0.36 & 0.18 & 0.30 \\
\hline & Compost & 0.05 & 0.02 & 0.05 & 0.02 & 0.01 & 0.02 \\
\hline & Compost to gardens & 0.14 & 0.06 & 0.14 & 0.06 & 0.03 & 0.05 \\
\hline & Sewage sludge to agriculture & 1.03 & 0.41 & 1.51 & 0.61 & 0.36 & 0.61 \\
\hline & Sewage sludge exported & 0.16 & 0.06 & 0.15 & 0.06 & 0.04 & 0.07 \\
\hline & Emission to air & 0.00 & 0.00 & 0.00 & 0.00 & 0.00 & 0.00 \\
\hline & Leaching landfills & 0.0003 & 0.0001 & 0.0003 & 0.0001 & 0.0001 & 0.0002 \\
\hline & Balance & 1.7 & 0.67 & 1.6 & 0.65 & 0.39 & 0.67 \\
\hline
\end{tabular}

1

4 products thereof), to inputs of sewage sludge and separately collected organic waste. This

5 assumes that all $\mathrm{P}$ in the organic waste stream entering the waste system is recoverable, which is

6 a theoretical upper limit and unlikely. Due to sludge incineration being concentrated in the

7 Copenhagen area, the ratio is lowest in region $\mathrm{A}$ at $47 \%$, with region $\mathrm{B}$ at $67 \%$ and region $\mathrm{C}$ at

$867 \%$. Over $50 \%$ of sewage sludge is applied on land, constituting the waste management

9 system's main output of P (Miljøstyrelsen 2013b). More than 60\% of organic waste,

10 predominantly plant waste such as garden and park waste (Andersen 2010; Miljøstyrelsen 2014)

11 is composted. Relatively little compost is used on agricultural land: compost P flows to

12 agricultural use constitute only a third of the flows to private and public non-agricultural land. P

13 accumulation in the waste management system is due to $\mathrm{P}$ accumulating in landfills via landfilled

14 incineration residues, or incineration slag \& ash used in construction (i.e. the cement industry).

15 This is the main pathway for losses of otherwise potentially recoverable $\mathrm{P}$ in the waste system. In

16 terms of regional per capita waste streams, this accumulation is comparable across regions at

17 approximately $0.7 \mathrm{~kg} \mathrm{cap}^{-1} \mathrm{yr}^{-1}$.

18

\section{3.2. Discussion}


In a European context, the Danish case is typical in its high dependence on imports of $\mathrm{P}$ in

2 fertiliser and feedstuffs. Compared to the EU-15 as an aggregate (Ott \& Rechberger 2012),

3 Denmark is characterised by higher per capita imports of P-containing goods other than primary

$4 \quad \mathrm{P}$, and by $\mathrm{P}$ in food exports surpassing the amounts of fertiliser imported. The external trade and

5 turnover of secondary $\mathrm{P}$ therefore plays a comparatively large role. In comparison to a recent

6 study of the Austrian P budget (Egle et al. 2014) the predominance of feedstuff imports to

7 support intensive animal husbandry in Denmark is even more salient. In the relative importance

8 of feedstuff imports, Denmark more closely resembles the Swiss case (Binder et al. 2009;

$9 \quad$ Lamprecht et al. 2011), although Danish food exports per capita (mainly animal products) clearly

10 surpass both those of Switzerland and Austria. The imports in food and feedstuffs (a total of 44

$11 \mathrm{Gg} \mathrm{yr}^{-1}$ ) compared to mineral fertiliser (12 $\left.\mathrm{Gg} \mathrm{yr}^{-1}\right)$, furthermore, point to potentially recoverable

$12 \mathrm{P}$ in organic wastes from the food production system and the resource potential of animal

13 manure. On the national level, the ratio of out- to inflows in Denmark is 0.66. For the entire, EU-

14 15, this ratio is 0.27 (Ott \& Rechberger 2012); an explanation for this is Denmark's relatively

15 high export of food (mainly, meat and dairy products).

16 A regionally differentiated study of the agriculture in four selected French regions, which

17 lends itself to comparison with the present study, was conducted for the base year 2006 by

18 Senthilkumar et al. (2011). In the French case, crop production is nearly the same in absolute

19 terms across all examined regions; differences in the P flows and stocks are due to different

20 animal densities in the regions, and the production of fodder versus food crops; this corresponds

21 to the contrast between regions A and C considered in this study. Danish regional soil P budgets

22 are comparable to the French case; both also correspond to differences in animal farming. The

23 predominance of crop or animal farming in region A and region C, respectively, appears more

24 pronounced than in any of the examined French regions. In terms of P nutrient use efficiency (the 
1 ratio of crop production to soil inputs), the Danish average (0.7) is similar to that of the four

2 French farming regions examined.

With respect to waste management and P recovery, studies of UK food production and consumption and French waste management (Cooper \& Carliell-Marquet 2013; Senthilkumar et

5 al. 2014) show similar utilization rates for sewage sludge $P$ on agricultural land. Danish sludge $P$

6 utilization in agriculture of over 50\% is higher than that in France 2006 (48\%), and lower than

7 that in the UK 2009 (71\%), although higher Danish claims of over 70\% also exist (Miljøstyrelsen

8 2013a). The P quantity of the entire amount of sewage sludge produced in Denmark equals $42 \%$

9 of $\mathrm{P}$ in mineral fertiliser imports, corresponding to the findings in the Austrian case (Egle et al.

10 2014). In the case of Switzerland (Binder et al. 2009), use of sludge on land is legally constricted

11 and was phased out; only $8.6 \%$ of sludge $\mathrm{P}$ was re-used in 2006 , with none used at present. The

12 French case highlights the potential of P recovery from the biowaste fraction of municipal waste:

$1349 \%$ of $\mathrm{P}$ in municipal waste was recovered from household bio-waste. The corresponding

14 Danish amount (i.e. the total P quantity in household biowaste; see Section 2.2.2.) is

15 approximately $60 \%$ of $\mathrm{P}$ in MSW that is currently not utilised, although $\mathrm{P}$ is recoverable from

16 this flow (e.g. composting). This amounts to a country-wide average potential of approximately

$1714 \%$ of the $\mathrm{P}$ in mineral fertilisers applied. Even if all of the $\mathrm{P}$ in household biowaste was

18 recovered and made fully as available as a substitute for mineral fertiliser $\mathrm{P}$, it would only

19 potentially substitute up to $1.6 \mathrm{Gg} \mathrm{P}$ out of the total $12 \mathrm{Gg}$ of mineral fertiliser $\mathrm{P}$ imported for

20 agriculture. A complete recycling of sewage sludge P to agriculture would add another 2.6 Gg of

21 P, so a total potential of less than $40 \%$ of current mineral fertiliser P imports.

Table 4 Additional non-recovered P quantities in sewage sludge and the MSW biowaste

24 fraction (2011), countrywide and within the respective region. The table shows the non-recovered $25 \mathrm{P}$ amounts in $\mathrm{Gg} \mathrm{P} \mathrm{yr}^{-1}$, and in \% of mineral fertiliser $\mathrm{P}$ applied. 


\begin{tabular}{lrrrr}
\hline & Denmark & Region A & Region B & Region C \\
\hline Sewage sludge P [Gg P yr ${ }^{-1}$ ] & 1.59 & 0.96 & 0.51 & 0.12 \\
\% of applied mineral fertiliser P & $15 \%$ & $33 \%$ & $8 \%$ & $8 \%$ \\
& & & & \\
MSW biowaste fraction [Gg P yr ${ }^{-1]}$ & 2.23 & 0.70 & 0.76 & 0.18 \\
\% of applied mineral fertiliser P & $21 \%$ & $24 \%$ & $12 \%$ & $12 \%$ \\
\hline
\end{tabular}

A more efficient use of recoverable $\mathrm{P}$ sources is to a large part a distribution and policy

3 problem; at present, virtually all recovered P stays local. Table 4 shows the intra-regional

4 additional amounts of $\mathrm{P}$ in two waste streams: $\mathrm{P}$ in the biowaste fraction in MSW, and $\mathrm{P}$ in the

5 fraction of sewage sludge not used on agricultural land. Sewage sludge is most abundant in the

6 east of the country (region A in this study), with the country's largest urban agglomeration,

7 highest proportion of crop production in agriculture, and highest mineral fertiliser use; the highest

8 amounts of sludge P coincide with a high potential for substitution. The recycling rate of total P

9 to land by direct application of sewage sludge is higher than 95\%; however, the large volumes of

10 sludge reduce possible transport distances (Lederer \& Rechberger 2010; Miljøstyrelsen 2013a).

11 Sludge mono-incineration is likewise concentrated in region A (all three Danish facilities);

12 separate disposal of mono-incineration ash for later recovery of $\mathrm{P}$ can reduce these volumes and

13 may reduce transport distances in the future. Possible barriers to the use of sewage sludge on

14 agricultural land are contaminants, especially heavy metals. Lederer \& Rechberger (2010) show

15 that the transfer of these substances to agricultural soil from either directly applied sludge or ash

16 is similar. While data on the amounts of sludge fulfilling the requirements were not freely

17 available, the authorities report that most sewage sludge is within the legal contaminant limits

18 (Miljøstyrelsen 2013b). Of course, other environmental harm is caused by the emissions from

19 transportation of sludge or products thereof. Building on an MFA identifying relevant quantities

20 of recoverable $\mathrm{P}$ in a geographical region's waste streams, a more detailed mapping (see e.g.

21 GIS-based approaches such as Wallsten et al. (2013) for copper stocks in Norrköping, Sweden) 
1 of distributable $\mathrm{P}$ amounts can thus be useful to plan for the location and capacities of treatment

2 facilities and minimize further environmental impacts from transport.

3 At present, slaughterhouse waste is predominantly incinerated, with the exception of the

$4 \quad$ use as feed in the fur industry concentrated in the west and northwest of Denmark, and use in

5 biofuel production. Citing an approximate total amount of $3 \mathrm{Gg}$ of $\mathrm{P}$ in slaughterhouse waste, the

6 Danish Environmental Protection Agency (Miljøstyrelsen 2013a) suggests separate incineration

7 of slaughterhouse waste and storage of incineration ash, as also suggested for sewage sludge, to

8 build up "phosphorus banks" for later treatment and recovery of $\mathrm{P}$ from incineration ashes with

9 relatively high P concentrations. This has likewise been suggested e.g. for Switzerland

10 (Lamprecht et al. 2011). In the case of slaughterhouse waste, especially meat and bone meal,

11 risks from animal-borne disease are in conflict with the objective of increased P recycling In the

12 Swiss case, however, a precautionary ban on fertilizer use also extends to sewage sludge (due to

13 the risks posed by micropollutants).

14 The transport problem is more pronounced in the case of manure. For improving societal

15 P use efficiency, current regulations, economic incentives and technical solutions for enhanced

16 relocation of animal manure $\mathrm{P}$ from farms with manure P surplus to farms where it can substitute

17 mineral fertiliser $\mathrm{P}$ will be crucial. Centralised biogas plants do not contribute to the

18 redistribution of recovered $\mathrm{P}$ as such, but may eventually become a vehicle for transforming the

19 manure P relocation issue, if the right technologies (e.g. mechanical separation) are implemented

20 in conjunction with the biogas plants. The Netherlands is an example of a manure policy

21 involving transport of manures over long distances. $23 \%$ of the manure produced is transported to

22 crop-producing farms within the country, up to a distance of approximately $150 \mathrm{~km}$ in the case of

23 liquid manure, and exported $300 \mathrm{~km}$ after mechanical separation or digestion/drying (Leenstra et

24 al. 2014). When compared to the Danish situation, transport distances within the country 
1 (between region $\mathrm{C}$ and $\mathrm{A}$ in this study) are up to $400 \mathrm{~km}$. Eliminating the $\mathrm{P}$ surplus of $3 \mathrm{Gg}$ in

2 region $\mathrm{C}$ (balancing the regional $\mathrm{P}$ budget) would correspond to $14 \%$ of total manure produced in

3 the country.

The goal of this study was the identification and quantification of P flows and stocks from

5 a resource recovery perspective. Complementing an MFA of $\mathrm{P}$ as a resource, a similar sub-

6 national, regional approach in MFA can elucidate the environmental harm potential of regional P

7 management, taking into account the sinks of $\mathrm{P}$ losses, as well as soil types and the leaching

8 behaviour of $\mathrm{P}$ from those soils.

10 4. CONCLUSIONS

As the substance flow diagrams in this study highlight, nutrient quantity in manure holds

12 the most conspicuous potential for mineral fertiliser substitution, although it is currently not 13 recycled in the most effective way.

14 Conversely, a more extensive recovery and use of P from sewage sludge by either direct

15 application on land or application after further treatment appears to be the most meaningful

16 option for more efficient P management in Sjælland and the capital region (region A), where high

17 amounts of sewage sludge and other P-rich wastes coincide with the largest proportion in crop

18 production and mineral fertiliser use, pointing to a considerable additional substitution potential.

19 The P from sewage sludge currently used on land amounts to $20 \%$ of P imported in

20 mineral fertilisers. The amount of $\mathrm{P}$ from organic household and green waste, as compost,

21 presently used on agricultural land is negligible at $0.9 \%$ of fertiliser imports. The biowaste

22 fraction of household waste is currently not collected separately and hence unused by agriculture,

23 constituting an entirely unused potential of $14 \%$ of mineral fertiliser $\mathrm{P}$ imports. The current

24 contribution to nutrient provision of farm-scale and joint farm-scale biogas plants by land 
1 spreading of digestate originating mostly from farmyard manure, and the manure flows to the

2 facilities, is still relatively minor compared to fertiliser use and direct application of manure, at

$39 \%$ of mineral fertiliser P applied. Biogas may play a more important future role in creating more

4 transportable recycled P products.

5 Current potential amounts of recoverable P cannot be expected to change the reliance on

6 mineral P. In terms of total P amounts, there is considerable potential in the waste management

7 system to substitute mineral fertiliser imports, although the relevant individual flows are

8 generally more than one order of magnitude smaller than P flows in mineral fertiliser and

9 manure, with sewage sludge holding the highest potential. This regionalised study shows the

10 varying potentials of putting recovered $\mathrm{P}$ to its most efficient use: utilizing recovered $\mathrm{P}$ is still a

11 largely local issue. Availability of manure is highest in the regions with the least demand, so this

12 requires technologies for processing and concentration of manure nutrients into tradable and

13 transportable fertilisers. Distribution for more efficient re-use of $\mathrm{P}$ is thus a policy problem, since

14 transport distances for farmyard manure, and sludge or sludge products, are currently limited to

15 the local scale.

\section{Acknowledgements}

This research was funded by the Danish Council for Strategic Research (Innovation Fund)

20 as part of the IRMAR (Integrated Resource Management \& Recovery) project at the Technical

21 University of Denmark. We would like to thank David Laner (Vienna University of Technology)

22 for providing valuable input during the drafting process. 
Andersen, Jacob Kragh. 2010. "Composting of Organic Waste: Quantification and Assessment of Greenhouse Gas Emissions.” Danmarks Tekniske Universitet.

Antikainen, Riina, Reija Haapanen, and Seppo Rekolainen. 2004. "Flows of Nitrogen and Phosphorus in Finland - the Forest Industry and Use of Wood Fuels.” Journal of Cleaner Production 12 (8-10) (October): 919-934. doi:10.1016/j.jclepro.2004.02.027. http://linkinghub.elsevier.com/retrieve/pii/S0959652604001003. Accessed 06-20-2013.

Ashley, Ken, Dana Cordell, and Don Mavinic. 2011. "A Brief History of Phosphorus: From the Philosopher's Stone to Nutrient Recovery and Reuse.” Chemosphere 84 (6) (August): 737_ 46. doi:10.1016/j.chemosphere.2011.03.001. http://www.ncbi.nlm.nih.gov/pubmed/21481914.

Baccini, Peter, and Paul H. Brunner. 2012. Metabolism of the Anthroposphere. 2nd ed. Cambridge (MA): MIT Press.

Binder, Claudia R., Laura de Baan, and Dominic Wittmer. 2009. Phosphorflüsse Der Schweiz. Bern: Bundesamt für Umwelt. http://www.bafu.admin.ch/publikationen/publikation/01516/index.html?lang=de\&downloa d=NHzLpZig7t,lnp6I0NTU04212Z6ln1acy4Zn4Z2qZpnO2Yuq2Z6gpJCGd313fmym162dp YbUzd,Gpd6emK2Oz9aGodetmqaN19XI2IdvoaCVZ,s-.pdf. Accessed 07-01-2013.

Birkmose, Torkild, Kurt Hjort-Gregersen, and Kasper Stefanek. 2013. "Biomasse Til Biogasanlæg I Danmark - På Kort Og Langt Sigt.” Copenhagen. http://www.ens.dk/sites/ens.dk/files/undergrund-forsyning/vedvarendeenergi/bioenergi/biogas-taskforce/rapporter_taskforce/biomasser_til_biogasanlaeg.pdf. . Accessed 05-20-2014.

Bomans, E, K Fransen, A Gobin, J Mertens, P Michiels, H Vandendriessche, and N Vogels. 2005. “Addressing Phosphorus Related Problems in Farm Practice.” Vol. 32. Leuven. http://ec.europa.eu/environment/natres/pdf/phosphorus/AgriPhosphorusReport final.pdf. Accessed 15-12-2012.

Cencic, Oliver, and Helmut Rechberger. 2008. "Material Flow Analysis with Software STAN." Journal of Environmental Engineering \& Management 18 (1): 3-7. http://ser.cienve.org.tw/download/18-1/jeeam18-1_3-7.pdf. Accessed 04-10-2013.

Chowdhury, Rubel Biswas, Graham A. Moore, Anthony J. Weatherley, and Meenakshi Arora. 2014. "A Review of Recent Substance Flow Analyses of Phosphorus to Identify Priority Management Areas at Different Geographical Scales.” Resources, Conservation and Recycling 83 (February 2014): 213-228. doi:10.1016/j.resconrec.2013.10.014. http://linkinghub.elsevier.com/retrieve/pii/S0921344913002218. 
Cooper, James, and Cynthia Carliell-Marquet. 2013. "A Substance Flow Analysis of Phosphorus in the UK Food Production and Consumption System.” Resources, Conservation and Recycling (74): 82-100. doi:http://dx.doi.org/10.1016/j.resconrec.2013.03.001.

Cordell, Dana, Arno Rosemarin, Jaap J Schröder, and A L Smit. 2011. “Towards Global Phosphorus Security: A Systems Framework for Phosphorus Recovery and Reuse Options." Chemosphere 84 (6) (August): 747-58. doi:10.1016/j.chemosphere.2011.02.032. http://www.ncbi.nlm.nih.gov/pubmed/21414650.

De Ridder, Marjolein, Sijbren de Jong, Joshua Polchar, and Stephanie Lingemann. 2012. "Risks and Opportunities in the Global Phosphate Rock Market. Robust Strategies in Times of Uncertainty. Rapport No. 17/12/12.” The Hague.

EEA. 2005. "Source Apportionment of Nitrogen and Phosphorus Inputs into the Aquatic Environment. EEA Report No. 7/2005.” Copenhagen.

Egle, Lukas, Ottavia Zoboli, Simon Thaler, Helmut Rechberger, and Matthias Zessner. 2014. "The Austrian P Budget as a Basis for Resource Optimization.” Resources, Conservation and Recycling 83 (February): 152-162. doi:10.1016/j.resconrec.2013.09.009. http://linkinghub.elsevier.com/retrieve/pii/S0921344913001900.

European Commission. 2014. "Report on Critical Raw Materials for the EU.” Brussels. http://ec.europa.eu/enterprise/policies/raw-materials/files/docs/crm-report-on-critical-rawmaterials_en.pdf. Accessed 05-12-2012.

European Parliament, and European Council. 2008. Directive 2008/98/EC of the European Parliament and of the Council of 19 November 2008 on Waste and Repealing Certain Directives (Text with EEA Relevance). http://eur-lex.europa.eu/legalcontent/EN/TXT/?uri=CELEX:32008L0098. Accessed 03-06-2014.

Eurostat. 2013a. “AEI_PR_GNB: Gross Nutrient Balance.” http://ec.europa.eu/eurostat/web/agrienvironmental-indicators/data/database. Accessed 05-03-2013.

_. 2013b. "Use of Inorganic Fertilisers." http://appsso.eurostat.ec.europa.eu/nui/show.do?dataset=aei_fm_usefert\&lang=en. Accessed 05-03-2013.

Fødevarestyrelsen, 2015. “Animalske biprodukter til særlige fodringsformål.” http://www.foedevarestyrelsen.dk/Leksikon/Sider/Animalske-biprodukter-til-saerligefodringsformaal.aspx. Accessed 15-06-2015.

Hedbrant, Johan, and Louise Sörme. 2001. "Data Vagueness and Uncertainties in Urban HeavyMetal Data Collection.” Water, Air and Soil Pollution: Focus 1 (3-4): 43-53.

IFA, 2013. Production and International Trade: Phosphate Rock. International Fertilizer Industry Association: Statistics Databases. Available at: http://www.fertilizer.org//En/Statistics/Content_Files_Members_Statistics/Excel_Files/Pho sphate_Rock_member.aspx. Accessed 12-02.2013. 
Jeppesen, Erik, Martin Søndergaard, Brian Kronvang, Jens P Jensen, Lars M Svendsen, and Torben L Lauridsen. 1999. "Lake and Catchment Management in Denmark.” Hydrobiologia (395/396): 419-432.

Kalmykova, Yuliya, and K Karlfeldt Fedje. 2013. "Phosphorus Recovery from Municipal Solid Waste Incineration Fly Ash.” Waste Management (New York, N.Y.) 33 (6) (June): 1403-10. doi:10.1016/j.wasman.2013.01.040. http://www.ncbi.nlm.nih.gov/pubmed/23490361.

Kjær, Birgitte. 2013. “Municipal Waste Management in Denmark.” Copenhagen. http://www.eea.europa.eu/publications/managing-municipal-solid-waste/denmarkmunicipal-waste-management. Accessed13-04-2013.

Kjeldsen, Peter, Morton A. Barlaz, Alix P. Rooker, Anders Baun, Anna Ledin, and Thomas H. Christensen. 2002. "Present and Long-Term Composition of MSW Landfill Leachate: A Review." Critical Reviews in Environmental Science and Technology 32 (4) (October): 297-336. doi:10.1080/10643380290813462. http://www.tandfonline.com/doi/abs/10.1080/10643380290813462.

Kjeldsen, Peter, and Mette Christophersen. 2001. "Composition of Leachate from Old Landfills in Denmark.” Waste Management \& Research 19 (3) (June 1): 249-256. doi:10.1177/0734242X0101900306. http://wmr.sagepub.com/cgi/doi/10.1177/0734242X0101900306.

Lamprecht, Heinz, Daniel J. Lang, Claudia R. Binder, and Roland W. Scholz. 2011. "The Tradeoff between Phosphorus Recycling and Health Protection during the BSE Crisis in Switzerland: A ‘Disposal Dilemma.'” Gaia 20 (2): 112-121.

Laner, David, Helmut Rechberger, and Thomas Fruergaard Astrup. 2015. "Applying Fuzzy and Probabilistic Uncertainty Concepts to the Material Flow Analysis of Palladium in Austria." Journal of Industrial Ecology. doi:10.1111/jiec.12235. http://doi.wiley.com/10.1111/jiec.12235.

Lederer, Jakob, and Helmut Rechberger. 2010. "Comparative Goal-Oriented Assessment of Conventional and Alternative Sewage Sludge Treatment Options.” Waste Management (New York, N.Y.) 30 (6) (June): 1043-56. doi:10.1016/j.wasman.2010.02.025. http://www.ncbi.nlm.nih.gov/pubmed/20219338.

Leenstra, Ferry, Theun Vellinga, Francesca Neijenhuis, and Fridtjof de Buisonjé. 2014. "Manure - a Valuable Resource.” Wageningen UR Livestock Research.

Miljøministeriet. 2010. "Bekendtgørelse Om Ændring Af Bekendtgørelse Om Husdyrbrug Og Dyrehold for Mere End 3 Dyreenheder, Husdyrgødning, Ensilage M.v.” https://www.retsinformation.dk/Forms/R0710.aspx?id=132871. Accessed 05-08-2014.

Miljøstyrelsen. 2011. “Affaldsstatistik 2009 Og Fremskrivning Af Affaldsmængder 2011-2050.” Orientering Fra Miljøstyrelsen Nr. 4/2011. Copenhagen. 
. 2013a. "Miljøprojekt Nr. 1460: Innovationspartnerskab for Anvendelse Af Fosfor Fra Spildevand Og Spildevandsslam Fra Spildevandsforsyninger.” Copenhagen.

—. 2013b. "ISAG Dataudtræk."

http://www2.mst.dk/databaser/isag/Default.asp?help=Yeshttp://www.mst.dk/Virksomhed_o g_myndighed/Affald/Tal_for_affald/Statistikker_og_ISAG-dataudtraek/ISAG.htm. Accessed 23-04-2013.

—. 2014. "Affaldsstatistik 2012." Copenhagen. http://mst.dk/media/129664/affaldsstatistikken-2012.pdf. Accessed 23-01-2014.

Møller, Henrik B, Alastair James Ward, Sebastiano Falconi, and Peter Mejnertsen. 2011. "Produktion Af Biogas Fra Husdyrgødning Og Afgrøder I Økologisk Landbrug. Intern Rapport Nr. 105, Maj 2011.” Aarhus.

Muñoz, Ivan, Llorenç Milà i Canals, Roland Clift, and Gabor Doka. 2007. "A Simple Model to Include Human Excretion and Wastewater Treatment in Life Cycle Assessment of Food Products. CES Working Paper 01/07.” 01/07. CES Working Paper. Guildford.

Naturerhvervstyrelsen. 2013. "Amounts and Types of Fertilisers Used, by Farm (personal Correspondence).” Copenhagen: Personal correspondence, Naturerhvervsstyrelsen.

Naturstyrelsen. 2011. “Introduktion Til Biogasanlæg.” Copenhagen. http://naturstyrelsen.dk/media/nst/8795722/Introduktiontilbiogasanlg.pdf. Accessed 05-082013.

— . 2012. "Punktkilder 2011." Copenhagen. http://naturstyrelsen.dk/media/nst/66851/Punktkilderapport 2011.pdf. Accessed 22-022013.

Nesme, Thomas, Samuel Brunault, Alain Mollier, and Sylvain Pellerin. 2011. "An Analysis of Farmers' Use of Phosphorus Fertiliser in Industrial Agriculture: A Case Study in the Bordeaux Region (south-Western France).” Nutrient Cycling in Agroecosystems 91 (1) (August 5): 99-108. doi:10.1007/s10705-011-9449-x. http://link.springer.com/10.1007/s10705-011-9449-x.

OECD. 2013. "Wastewater Treatment (\% Population Connected).” OECD StatExtracts. http://stats.oecd.org/Index.aspx?DataSetCode=WATER_TREAT. Accessed 21-02-2013.

OECD, and Eurostat. 2007. “Gross Phosphorus Balances: Handbook.” www.oecd.org/tad/env/indicators. Accessed 05-03-2013.

Ott, Christian, and Helmut Rechberger. 2012. "The European Phosphorus Balance.” Resources, Conservation and Recycling 60 (March): 159-172. doi:10.1016/j.resconrec.2011.12.007. http://linkinghub.elsevier.com/retrieve/pii/S0921344911002540. 
Plantedirektoratet. 2014. "Tabel 8 : Beregning Af Dyreenheder.” Copenhagen. http://www.pdir.dk/Files/Filer/Topmenu/Publikationer/Vejledninger/Goedningsregnskab02 03/tab08.htm. Accessed 05-10-2014.

Poulsen, Hanne Damgaard, and Gitte Holton Rubæk. 2005. “DJF Rapport Fosfor I Dansk Landbrug. Omsætning, Tab Og Wirkemidler Mod Tab. DJF Rapport Husdyrbrug Nr. 68 • December 2005.” Tjele.

Rambøll. 2012. “Waste-to-Energy State-of-the-Art-Report.” Copenhagen.

Raven, R.P.J.M., and K.H. Gregersen. 2005. "Biogas Plants in Denmark: Successes and Setbacks.” Renewable and Sustainable Energy Reviews 11 (1): 1-18. doi:10.1016/j.rser.2004.12.002. http://linkinghub.elsevier.com/retrieve/pii/S1364032105000092.

Riber, Christian, Claus Petersen, and Thomas H Christensen. 2009. "Chemical Composition of Material Fractions in Danish Household Waste.” Waste Management (New York, N.Y.) 29 (4) (April): 1251-7. doi:10.1016/j.wasman.2008.09.013. http://www.ncbi.nlm.nih.gov/pubmed/19062265.

Rohold, Lars. 2011. "Biogas in Denmark - Status and Framework Conditions.” Presentation atBiogass11. Ørland. http://docslide.us/documents/biogas-in-denmark-status-andframework-conditions-biogass11-march-09-2011-lars-rohold-danish-biogasassociation.html. Accessed 20-10-2013.

Rittmann, Bruce E, Brooke Mayer, Paul Westerhoff, and Mark Edwards. 2011. "Capturing the Lost Phosphorus.” Chemosphere 84 (6) (August): 846-53. doi:10.1016/j.chemosphere.2011.02.001. http://www.ncbi.nlm.nih.gov/pubmed/21377188.

Rubæk, Gitte H., Goswin Heckrath, and Leif Knudsen. 2005. “Fosfor I Dansk Landbrugsjord.” Markbrug 312 (2005).

Rubæk, Gitte H., Kristian Kristensen, Svend E. Olesen, Hans S. Østergaard, and Goswin Heckrath. 2013. "Phosphorus Accumulation and Spatial Distribution in Agricultural Soils in Denmark.” Geoderma 209-210 (November): 241-250. doi:10.1016/j.geoderma.2013.06.022. http://linkinghub.elsevier.com/retrieve/pii/S001670611300222X.

Scholz, Roland W., and Friedrich Wilhelm Wellmer. 2013. "Approaching a Dynamic View on the Availability of Mineral Resources: What We May Learn from the Case of Phosphorus?" Global Environmental Change 23 (1): 11-27. doi:10.1016/j.gloenvcha.2012.10.013. http://dx.doi.org/10.1016/j.gloenvcha.2012.10.013.

Scholz, Roland W., Amit H. Roy, and Deborah T. Hellums. 2014. Sustainable Phosphorus Management: A Transdisciplinary Challenge. In: Scholz, Roland W, Amit H Roy, Fridolin S Brand, Deborah T Hellums, and Andrea E Ulrich (Editors). Sustainable Phosphorus Management. Berlin: Springer. doi:10.1007/978-94-007-7250-2. 
Schröder, Jaap J., AL Smit, Dana Cordell, and Arno Rosemarin. 2011. "Improved Phosphorus Use Efficiency in Agriculture: A Key Requirement for Its Sustainable Use.” Chemosphere 84 (6) (August): 822-31. doi:10.1016/j.chemosphere.2011.01.065. http://www.ncbi.nlm.nih.gov/pubmed/21349568.

Senthilkumar, Kalimuthu, Alain Mollier, Magalie Delmas, Sylvain Pellerin, and Thomas Nesme. 2014. "Phosphorus Recovery and Recycling from Waste: An Appraisal Based on a French Case Study.” Resources, Conservation and Recycling 87 (June): 97-108. doi:10.1016/j.resconrec.2014.03.005. http://linkinghub.elsevier.com/retrieve/pii/S0921344914000639.

Senthilkumar, Kalimuthu, Thomas Nesme, Alain Mollier, and Sylvain Pellerin. 2011. "RegionalScale Phosphorus Flows and Budgets within France: The Importance of Agricultural Production Systems." Nutrient Cycling in Agroecosystems 92 (2) (December 15): 145-159. doi:10.1007/s10705-011-9478-5. http://www.springerlink.com/index/10.1007/s10705-0119478-5.

Sharpley, Andrew. 1995. "Fate and Transport of Nutrients : Phosphorus. Working Paper No. 8." Durant, Oklahoma. http://www.nrcs.usda.gov/wps/portal/nrcs/detail/national/technical/nra/rca/?\&cid=nrcs143_ 014203.Accessed 28-03-2014.

Sibbesen, Erik, and Artur Runge-Metzger. 1992. "Phosphorus Balance In European Agriculture Status And Policy Options.” In SCOPE, edited by H. Thiessen. New York: Wiley.

Smil, Vaclav. 2000. "Phosphorus in the Environment: Natural Flows and Human Interferences.” Annual Review of Energy and the Environment 25: 53-88.

Sokka, Laura, Riina Antikainen, and Pekka Kauppi. 2004. "Flows of Nitrogen and Phosphorus in Municipal Waste : A Substance Flow Analysis in Finland.” Progress in Industrial Ecology 1 (1/2/3): 165-186.

Sommer, Sven G, Henrik B Møller, and Søren O Petersen. 2001. "Reduktion Af Drivhusgasemission Fra Gylle Og Organisk Affald Ved Biogasbehandling. DJF Rapport Husdyrbrug Nr. 31 • July 2001.” Tjele.

Sørensen, Claus A G, Sven G Sommer, Dionysis Bochtis, and Alan Rotz. 2013. "Technologies and Logistics for Handling, Transport and Distribution of Animal Manures.” In Animal Manure Recycling: Treatment and Management, edited by S. G. Sommer, M. L. Christensen, T. Schmidt, and L. S. Jensen, 211-236. Chichester, UK: Wiley \& Sons.

Statistics Denmark. 2013a. "AFG03: Farms and Area with Selected Crops by Region (province), Area with the Crop and Unit.” www.statbank.dk/afg3. Accessed 23-02-2013. 
_ 2013c. "ANI4: Slaughterings and Production of Cattle by Time, Category and Unit." www.statbank.dk/ani4. Accessed 22-02-2013.

3

_ 2013d. "ANI5: Slaughterings and Production of Pigs by Time, Category and Unit." www.statbank.dk/ani5. Accessed 22-02-2013.

_. 2013e. "ANI6: Slaughterings and Production of Poultry by Time, Category and Unit." www.statbank.dk/ani6. Accessed 22-02-2013.

_ 2013f. “ANI7: Production and Use of Milk by Unit.” www.statbank.dk/ani7. Accessed 22-02-2013.

_. 2013g. "BRUG66: Farms by Kind, Time, Type of Farm and Region.” www.statbank.dk/brug66. Accessed 20-02-2013.

— . 2013h. "FODER1: Feed Stuffs in Agriculture by Time, Unit, Type of Fodder and Origin." www.statbank.dk/foder1. Accessed 26-02-2013.

— . 2013i. "FRO: Grass Seed Production by Time, Crop and Unit." www.statbank.dk/fro. Accessed 23-02-2013.

—. 2013j. "GARTN1: Production of Fruit and Vegetables by Unit, Time, Region and Crop." www.statbank.dk/GARTN1. Accessed 23-02-2013.

_. 2013k. "HALM1: Straw Yield and Use by Unit, Time, Use, Region and Crop." www.statbank.dk/halm1. Accessed 15-03-2013.

—. 2013l. "HDR07: Livestock by Unit, Time, Region and Type.” www.statbank.dk/hdr07. Accessed 23-02-2013.

_ 2013m. "HST77: Harvest by Unit, Time, Region and Crop.” www.statbank.dk/hst77. Accessed 23-02-2013.

_ 2013n. "KN8M: Imports and Exports CN (EU Combined Nomenclature) by Imports and Exports, Commodities, Country and Unit.” www.statbank.dk/knm8. Accessed 15-01-2013.

—. 20130. "KVAEG5: Number of Cattle by Time, Region and Type." www.statbank.dk/kvaeg5. Accessed 24-02-2013.

— 2013p. "KVAEL2: Total Supply of Mineral Fertilizers/content of Pure Nutrients by Unit of Measurement, Time and Type of Substance.” www.statbank.dk/kvael2. Accessed 20-022013. 
1 . 2013r. "PELS22: Farms with Furred Animals by Time, Farm Information and Region.”

$2 \quad$ www.statbank.dk/pels22. Accessed 02-04-2013.

3 . 2013s. "SKOV1: Forestry Area by Region, Time and Forest Area."

$4 \quad$ www.statbank.dk/skov1. Accessed 28-03-2013.

5 - 2013t. "SKOV6: Felling in Forests and Plantation in Denmark by Time, Area, Species of $6 \quad$ Wood and Region.” www.statbank.dk/skov6. Accessed 28-03-2013.

7 . 2013u. "VARER: Industrial Commodity Statistics by Commodity Group and Unit."

$8 \quad$ www.statbank.dk/VARER. Accessed 14-01-2013.

9 - 2013v. "VHUS1: Greenhouses by Structure, Time and Region.”

$10 \quad$ www.statbank.dk/vhus1. Accessed 02-03-2013.

11 Technical University of Denmark. 2009. “Danish Food Composition Databank.”

12 http://www.foodcomp.dk/download/DKFoodcomp701_2009-03-12_xls.zip. Accessed 02-

$13 \quad 06-2015$.

14 Vinther, Finn P, and Preben Olsen. 2011. "Nutrient Balances and Nutrient Surpluses in Danish

15 Agriculture 1989-2009 (2010) Nitrogen Phosphorus Potassium.” Vol. 2009. Aarhus.

16 . 2013. "Næringsstofbalancer Og Næringsstofoverskud I Landbruget 1991/92-2011/12.

17 DCA Rapport Nr. 025.” Aarhus. http://web.agrsci.dk/djfpublikation/djfpdf/dca_rapport25-

18 2013.pdf. Accessed 02-10-2014. 